\title{
Utilization of Complex Carbon Sources on Biofloc System and Its Influence on the Microbial Composition, Growth, Digestive Enzyme Activity of Pacific White Shrimp, Penaeus vannamei Culture
}

\author{
Saranya Chakrapani ${ }^{1}\left(\mathbb{D}\right.$, Akshaya Panigrahi $^{1, *}\left(\mathbb{D}\right.$, Jayashree Sundaresan ${ }^{1}\left(\mathbb{D}\right.$, Sundaram $^{-}$ \\ Mani $^{1}{ }^{(D}$, Esakkiraj Palanichamy $\left.{ }^{1}{ }^{(}\right)$, Vinothkannan Sithu Rameshbabu ${ }^{1}(\mathbb{D}$, \\ Ambiganandham Krishna ${ }^{1}$
}

${ }^{1}$ ICAR - Central Institute of Brackishwater Aquaculture, 75, Santhome High Road, R. A. Puram, Chennai, India.

\section{How to cite}

Chakrapani, S., Panigrahi, A., Sundaresan, J., Mani, S., Palanichamy, E., Rameshbabu, V.S., Krishna, A. (2022). Utilization of Complex Carbon Sources on Biofloc System and Its Influence on the Microbial Composition, Growth, Digestive Enzyme Activity of Pacific White Shrimp, Penaeus vannamei Culture. Turkish Journal of Fisheries and Aquatic Sciences, 22(4), TRJFAS18813. http://doi.org/10.4194/TRJFAS18813

\section{Article History}

Received 21 January 2021

Accepted 09 December 2021

First Online 10 December 2021

Corresponding Author

Tel.: +919025739499

E-mail: panigrahi@ciba.res.in

\section{Keywords}

P. vannamei

Biofloc

16s rRNA

Real-time PCR

Digestive enzymes

\begin{abstract}
A two-month experiment was conducted to evaluate the effect of complex carbon sources on the biofloc system and its influence on Penaeus vannamei culture. Four sources of carbon viz. Tapioca flour (BFTf), Rice bran (BFRb), Wheat flour (BFWf), Rice Flour (BFRf), and biofloc were generated, the absence of $\mathrm{CHO}$ being considered as control (C). The experiment was carried out in 100L FRP tanks in triplicate, and the post-larvae (ABW: $0.11 \mathrm{~g}$ ) were stocked @ $400 \mathrm{PL} / \mathrm{m}^{3}$. Results revealed that the addition of complex carbon sources effectively reduces the TAN by $62-67 \%$. The average body weight of shrimp in the rice flour and wheat flour treatments were significantly higher compared to control. Similarly, improved survival was observed in rice bran treatment (89\%). Beneficial bacteria were isolated from all the treatments as well as control. Real-time analysis revealed significantly $(P<0.05)$ higher expression of digestive enzyme-related genes compared to control the utilization of carbohydrates, exhibiting an encouraging trend. The complex carbon sources (BFRf) and (BFWf) have been effectively utilized, resulting in improved water quality, microbial diversity, growth performance, and enhanced digestive enzyme activity.
\end{abstract}

\section{Introduction}

The increasing human population in today's world demands high production of nutritious food. The aquaculture industry is one of the primary foodproducing industries that play a significant role in food security, poverty alleviation, and affecting the economy in a positive manner. Shrimp aquaculture is ranked at eighth position production-wise and is second as far as global fish sales are concerned (Cai et al., 2017). The shrimp industry is a growing enterprise beset with problems such as excessive usage of water and land. Today, the biofloc technology in aquaculture utilizes limited water and land resources, consequent to which it can lead to an eco-friendly blue aquaculture industry (Bossier and Ekasari, 2017).

The main principle of the technology is the manipulation and maintenance of the $\mathrm{C}: \mathrm{N}$ ratio in the culture environment (Chakrapani et al., 2021). Balancing carbon and nitrogen in the aquaculture medium will stimulate faster growth of the heterotrophic bacterial population. The nitrogen assimilation by heterotrophic bacteria converts the toxic ammonium into microbial protein (Avnimelech, 2009; Crab et al., 2012; Panigrahi et al., 2018). However, the conversion is faster due to the rapid growth of heterotrophic bacteria in the biofloc system (Mugwanya et al., 2021). Heterotrophic bacterial biomass yield per substrate unit was tenfold higher than 
the nitrifying bacterial population (Hargreaves et al., 2006); this appears to be an economical way of removing the excess nitrogen. Further, the biofloc, a nutritious natural feed, reduces the cost of production by decreasing the percentage of protein in the feed (EISayed,2021). Hence it has a positive cascading effect in the culture system leading to improved water quality and growth performance.

Carbon and nitrogen ratio balancing is a crucial aspect of the biofloc system, and supplying a suitable carbon source determines the success of the technology. Several reports indicate that selecting appropriate carbon sources will determine the microbial community structure, function, and stability of biofloc (Hollender et al., 2002; Wei et al., 2016; Bakhshi et al., 2018; Romano et al., 2018; El-Sayed, 2021). While selecting the carbon sources, the following criteria need to be considered: nutritional composition, digestibility, economic viability, and continuous availability. The most commonly used carbon sources for biofloc development are molasses, glycerol, sugars such as dextrose, and agricultural by-products such as brans (Emerenciano et al., 2013: Dauda et al., 2017; Panigrahi et al.,2019b). Identifying new and locally available carbon sources is needed to develop biofloc technology. Complex carbon sources are reported to have a substantial impact on biofloc development and improved growth than when molasses is used (Mabroke et al., 2018). Since molasses and glycerol comprise simple sugars, complex carbon sources such as rice and wheat flour, rice bran, etc., which are made up of polysaccharides, have protein, lipids and other minor nutrients in addition to carbohydrates. The complex carbon sources can improve the nutritional values of biofloc and serve as additional food for the animals leading to improvement in body weight (Rajkumar et al., 2016; Verma et al., 2016).

On the other hand, simple carbon sources like glycerol can disperse quickly in the water and help reduce ammonia compared to complex carbon sources (Dauda et al., 2017). Hence, the simple carbon sources can be efficiently utilized by heterotrophic bacteria for multiplication resulting in e dispersion and quicker floc development. However, excess carbon source supplementation needs to be carried out in the culture tank. In contrast, the complex carbon sources of rice bran or wheat bran have complex nutrients which are decomposed slowly by heterotrophic bacteria. The slower dispersion of this carbon source aids in maintaining the floc formation in biofloc system. It also provides a stable response to the culture medium by reducing the nitrogen metabolites. (Khanjani et al., 2017). Hence, heterotrophic bacterial colonization is crucial in carbon sources, making them available to cultured animals. Heterotrophic bacterial population count and structure may vary depending on the carbon sources used for floc formation (Mabroke et al., 2018; Deng et al., 2018). This study replaced the complex carbon sources as a better alternative to the exhausted carbon sources. Our study evaluated the efficiency of different complex carbon sources supplementation on microbial community variation, growth, and survival of Penaeus vanammei cultured in the biofloc system.

\section{Materials and Methods}

\section{Experimental Design}

A 2-months experiment was carried out (triplicate) to evaluate the effect of complex carbon sources for biofloc generation and their influence on microbial colonization on $P$. vannamei culture. Four treatments viz. Tapioca flour (BFTf), Rice bran (BFRb), wheat flour (BFWf), and Rice flour (BFRf) were utilized for biofloc generation and compared to a control (C) that was devoid of any carbon source. The experiment was conducted in 100L FRP (Fiberglass reinforced tanks). For biofloc generation, the tanks were filled with disinfected seawater to which a concoction of biofloc inoculum was applied. Biofloc inoculum was prepared by fermenting the respective carbon sources with Bacillus subtilis (MTCC 2756) $\left(10^{9} \mathrm{CFU} / \mathrm{ml}\right.$ ) in sterile seawater ( 1 liter) for $24 \mathrm{hrs}$ after which it was filtered and added to the respective tanks. The animals $(0.11 \pm 0.02 \mathrm{~g})$ were stocked @ $400 \mathrm{PL} / \mathrm{m}^{-3}$. The experiment was maintained with C: N ratio of 15:1 (Avnimelech, 1999), and animals were fed daily @ 10\% of their biomass which was subsequently decreased to $1.5 \%$ at the end of the experiment. Continuous aeration was provided to facilitate proper mixing of the floc.

\section{Water Quality Parameters}

Physico-chemical parameters of the experimental water viz. temperature, $\mathrm{pH}$, and salinity were recorded daily using a mercury thermometer, pH-Scan-Eutech instrument (Singapore), and hand refractometer, respectively. Measured Total ammoniacal nitrogen (TAN) using phenol hypochlorite method, nitrite $\left(\mathrm{NO}_{2}-\right.$ $\mathrm{N})$, nitrate $\left(\mathrm{NO}_{3}-\mathrm{N}\right)$, Phosphate-P (PO4-P), total alkalinity, TSS, and chlorophylla every three days once (APHA, 1998). Settleable solids were measured using the Imhoff cone method daily.

\section{Growth Performance}

The shrimps were sampled once a fortnight. The average weight gain (AWG) (g), average daily growth g/day (ADG), specific growth rate (SGR), and survival (\%) were measured as follows:

Weight gain $(\%)=$ Final weight $(\mathrm{g})$ - Initial weight $(\mathrm{g}) \times 100$ Initial weight (mg)

Specific growth rate $(S G R)(\%)=($ In final weight $-\ln$ initial weight)/Days of culture $\times 100$ 
ADG (mg day-1) =Final weight (mg) - Initial weight (mg) Experimental duration (days)

\section{ADG: Average Daily Growth}

\section{Microbiological Analysis}

Biofloc samples from the respective treatments were collected once in 10 days, and the heterotrophic bacterial community in the samples was enumerated by using different agar plates. The total heterotrophic bacterial population was enumerated by using Zobell marine agar (ZMA). The total Vibrio count and total Bacillus count were observed by using TCBS agar and HiChrome Bacillus agar, respectively (Himedia, India). In brief, biofloc samples from different treatments were serially diluted, spread on to respective agar plates, and incubated for $24-48 \mathrm{~h}$ at $32^{\circ} \mathrm{C}$. After incubation, colonies with different morphology were chosen and stored at $4^{\circ} \mathrm{C}$. Further, the genomic DNA was isolated (Genejet genomic DNA purification kit, ThermofisherScientific, India) from the respective bacterial culture, and the $16 \mathrm{~s}$ rRNA gene was amplified. The PCR program used was as follows; initial denaturation at $94^{\circ} \mathrm{C}$ for $1 \mathrm{~min}$, followed by 35 cycles of denaturation at $94^{\circ} \mathrm{C}$ for $1 \mathrm{~min}$, annealing at $55^{\circ} \mathrm{C}$ for $45 \mathrm{sec}$ and extension at $72^{\circ} \mathrm{C}$ for $45 \mathrm{sec}$, with a final extension at $72^{\circ} \mathrm{C}$ for $10 \mathrm{~min}$ by using universal forward (27F) (5'-AGAGTTTGATCMTGGCTCAG-3') and reverse (1492R) (5'-TACGGYTACCTTGTTACGACTT-3') primers. The PCR product was purified (Genejet PCR purification kit, Thermofisher Scientific, India) and outsourced for sequencing (Agrigenome labs Pvt Ltd., Cochin, India). Further, bacteria from each treatment were identified using a similarity search with the BLAST search engine, and phylogenetic analysis was carried out with MEGA. 10. Software.

\section{Identification of the Planktonic Composition}

The water samples were collected from all the tanks and concentrated to $50 \mathrm{ml}$ by filtering through a plankton net. The planktonic water samples were fixed in 5\% formalin for further analysis (Pennak, 1978). The plankton was counted using a Sedgwick-Rafter counting cell. A $1 \mathrm{ml}$ sample was added into the rafter and kept undisturbed for $15 \mathrm{~min}$ for settling; later, the planktons were counted and represented as no of cells/liter (Asaduzzaman et al., (2010).

\section{Expression of Digestive Enzyme and Metabolism- related Genes by Real-time Analysis}

Animals $(n=6)$ were collected at the end of the experiment, and total RNA from the hepatopancreas was isolated using the RNeasy Mini Kit (Qiagen, USA). The mRNA was converted into complementary DNA using the iScript 1st Strand cDNA Synthesis Kit (Bio-Rad, USA). The digestive enzyme and metabolism-related gene expression were performed by using a genespecific primer as listed in Table. 1 . The reaction mixture consists of the total reaction volume $(20 \mu \mathrm{L})$ in each PCR tube of $10 \mu \mathrm{L}$ of $2 \mathrm{X} \mathrm{SYBR}^{\circledR}$ Green qPCR master mix (BioRad, USA), $1 \mu \mathrm{L}$ each of forward and reverse primers (10 pmol), $1 \mu \mathrm{L}$ of template DNA (30-60 ng) and $7 \mu \mathrm{L}$ of PCR water. A negative control without a CDNA template was run to assess the overall specificity. Two-step PCR reaction was carried out with the following temperature cycle; holding stage at $95^{\circ} \mathrm{C}$ for $10 \mathrm{~min}$ (initial denaturation), 45 cycles of $00.15 \mathrm{sec}$ at $95^{\circ} \mathrm{C}$ (denaturation) and $1 \mathrm{~min}$ at $60^{\circ} \mathrm{C}$ (annealing and extension) (Applied Biosystem's Real-Time PCR system StepOnePlus'). All the samples were analyzed in triplicate, and relative expression was calculated using

Table 1. List of primers used in the present study for mRNA expression of different digestive enzymes and metabolism-related gene expression in shrimp gut samples.

\begin{tabular}{|c|c|c|c|}
\hline Gene & Primer sequence $\left(5^{\prime}-3^{\prime}\right)$ & Accession no/Reference & Amplicon Size \\
\hline \multirow[t]{2}{*}{ Trypsin } & F- TCCTCTCCAAGATCATCCAA & Stephens et al., 2012 & $255 b p$ \\
\hline & R- GGCACAGATCATGGAGTC & & \\
\hline \multirow{2}{*}{ Chymotrypsin } & F- GGCTCTCTTCATCGACG & Stephens et al., 2012 & $266 b p$ \\
\hline & R- CGTGAGTGAAGAAGTCGG & & \\
\hline \multirow[t]{2}{*}{ Cathepsin L } & F-CTCAGGACGGTAAGTGTCG & Stephens et al., 2012 & $239 b p$ \\
\hline & R-TTCTTGACCAGCCAGTAGG & & \\
\hline \multirow[t]{2}{*}{ Cathepsin B } & F-GGATGTAACGGAGGCTTC & Stephens et al., 2012 & $212 b p$ \\
\hline & R-CTGTATGCTTTGCCTCCA & & \\
\hline \multirow[t]{2}{*}{$\alpha$-Amylase } & F-GGTAAACACTGACTCACGCC & AH013375.2 & $234 b p$ \\
\hline & R-TTCACGTCTCCCTGGTACAC & & \\
\hline \multirow[t]{2}{*}{ Pyruvate Kinase } & F- ATCCTTGATGGTGCTGAC & EF102105.1 & $133 \mathrm{bp}$ \\
\hline & R-CCGTGTTCGTTGAGAAGT & & \\
\hline \multirow[t]{2}{*}{ Fatty acid Synthase } & F-TACGGAGAACCTAGTGGAAC & HM595630 & $115 b p$ \\
\hline & R-CTACCGACGACGAAAAGTGA & & \\
\hline \multirow[t]{2}{*}{ Triacylglycerol lipase } & F-ACTGTCTCCTCTGCTCGTC & XM_027365317.1 & $148 \mathrm{bp}$ \\
\hline & R-ATGGTTTCTGGAATAGGTGTTT & & \\
\hline \multirow[t]{2}{*}{ ß-actin } & F-CAACCGCGAGAAGATGACAC & GU732815.1 & $243 b p$ \\
\hline & R-TCGGTCAGGATCTTCATCAGG & & \\
\hline
\end{tabular}


the comparative cycle threshold (CT) method (Pfaffl, 2001). CT is defined as the cycle number at which fluorescence reaches a set threshold value. The ß-actin gene expression was used as an internal control.

\section{Statistical Analysis}

The data were analyzed using SPSS (Version-17) software. One way ANOVA was deployed to compare the treatments and significance $(P<0.05)$ was tested using Duncan's Multiple Range test. Unless otherwise specified, the significance was tested at $5 \%$ probability level.

\section{Results}

\section{Assessment of Water Quality Parameters}

The water quality parameters are presented in Table 2. There was no significant difference in temperature, $\mathrm{pH}$, and salinity among the treatments and control. However, the level of $\mathrm{NH}_{4}-\mathrm{N} \mathrm{NO}_{2}-\mathrm{N}, \mathrm{NO}_{3}-\mathrm{N}$, and $\mathrm{PO}_{4}$ significantly varied $(\mathrm{P}<0.001)$ between treatments and control. Besides, $62-67 \%$ of the reduced TAN level was observed in the treatments. In particular, BFWf showed the highest decrease of TAN level than control, but there was no significant difference between the treatments $(P>0.05)$. All the treatments showed significantly higher values in TSS, settleable solids, and chlorophyll-a $(\mathrm{P}<0.001)$.

\section{Growth Performance}

Growth and survival of the shrimps after 60 days of rearing are depicted in Table 2 . Shrimps reared in biofloc generated with different carbon sources showed encouraging results. The survival in treatments ranged from 81 to $89 \%$, and a significantly $(P<0.05)$ higher survival was observed when compared to the control group (79\%) (Table 3). The average bodyweight of the biofloc reared shrimp at the end of rearing (BFRf: $5.4 \mathrm{~g}$, BFWf: 5.06g, BFTf: 4.86g, BFRb:4.48g) was significantly higher than the control (4.05g) (Figure 1). Overall, the specific growth rate and average daily weight gain were significantly higher $(P<0.01)$ in BFRf followed by other treatments (range from 0.079 to $0.088 \mathrm{~g}$ ) and control $(0.066 \mathrm{~g})$, and their corresponding SGR varied between 6.0-6.4\% day ${ }^{-1}$ (Table 3).

\section{Microbiological Analysis}

Microbiological analysis of the total viable count revealed higher values in biofloc treatments compared to control. Among the four different carbon sources used, BFRf showed a higher bacterial count $\left(3.9 \times 10^{4}\right)$, followed by BFWf $\left(3.3 \times 10^{4}\right)$. The total viable count of $\operatorname{BFTf}\left(2.9 \times 10^{4}\right)$ and BFRb $\left(2.9 \times 10^{4}\right)$ was also on the higher side compared to control $\left(1.9 \times 10^{4}\right)$. The total Vibrio in different treatments appeared too low to facilitate counting compared to control $\left(1.4 \times 10^{2}\right)$. In addition, colonies were observed in HiChrome Bacillus agar, and

Table 2. Water quality parameters of biofloc-based shrimp culture and control groups. It represents the mean \pm SD. Mean in the same row having different superscript differs significantly.

\begin{tabular}{|c|c|c|c|c|c|c|}
\hline \multirow[t]{2}{*}{ Parameter } & Control & BFTf & BFRb & BFWf & BFRf & \multirow[t]{2}{*}{$p$ value } \\
\hline & Mean \pm SD & Mean \pm SD & Mean \pm SD & Mean \pm SD & Mean \pm SD & \\
\hline Temperature $\left({ }^{\circ} \mathrm{C}\right)$ & $33^{\mathrm{a}} \pm 1.2$ & $33^{\mathrm{a}} \pm 1.2$ & $33^{a} \pm 1.4$ & $32^{\mathrm{a}} \pm 1.2$ & $33^{a} \pm 1.3$ & NS \\
\hline $\mathrm{pH}$ & $7.7^{\mathrm{a}} \pm 0.0$ & $7.6^{\mathrm{a}} \pm 0.1$ & $7.6^{\mathrm{a}} \pm 0.0$ & $7.5^{\mathrm{a}} \pm 0.1$ & $7.7^{a} \pm 0.1$ & NS \\
\hline Salinity (ppt) & $34.5^{\mathrm{a}} \pm 0.9$ & $34.3^{\mathrm{a}} \pm 0.5$ & $34.6^{\mathrm{a}} \pm 0.5$ & $34.2^{\mathrm{a}} \pm 0.4$ & $34.5^{\mathrm{a}} \pm 0.8$ & NS \\
\hline Alkalinity $\mathrm{CaCO}_{3}(\mathrm{ppm})$ & $134^{\mathrm{a}} \pm 2.8$ & $154.1^{b} \pm 7.7$ & $148^{\mathrm{b}} \pm 8.4$ & $150^{\mathrm{b}} \pm 8.4$ & $157^{b} \pm 2.1$ & $0.001 *$ \\
\hline Nitrite $\left(\mathrm{NO}_{2}\right)(\mathrm{ppm})$ & $0.64^{d} \pm 0.5$ & $0.36^{\mathrm{a}} \pm 0.3$ & $0.51^{c} \pm 0.5$ & $0.42^{b} \pm 0.5$ & $0.40^{\mathrm{ab}} \pm 0.5$ & $0.001 *$ \\
\hline Nitrate $\left(\mathrm{NO}_{3}\right)(\mathrm{ppm})$ & $1.55^{\mathrm{d}} \pm 1.4$ & $1.40^{c} \pm 1.2$ & $1.32^{b} \pm 1.5$ & $1.23^{\mathrm{a}} \pm 1.4$ & $1.43^{c} \pm 1.3$ & $0.001 *$ \\
\hline Total Ammonia-nitrogen (ppm) & $0.69^{b} \pm 0.6$ & $0.40^{\mathrm{a}} \pm 0.5$ & $0.41^{\mathrm{a}} \pm 0.7$ & $0.37^{a} \pm 0.4$ & $0.41^{a} \pm 0.3$ & $0.001 *$ \\
\hline Orthophosphate $\mathrm{PO}_{4}(\mathrm{ppm})$ & $1.85^{c} \pm 1.5$ & $3.33^{b} \pm 2.0$ & $3.20^{\mathrm{ab}} \pm 2.0$ & $3.88^{\mathrm{a}} \pm 1.3$ & $3.06^{c} \pm 2.3$ & $0.001 *$ \\
\hline Chlrophyll $\left(\mu \mathrm{g} \mathrm{L}^{1}\right)$ & $69.7^{a} \pm 6.3$ & $117.9^{b} \pm 5.6$ & $120.3^{b} \pm 3.5$ & $120.1^{b} \pm 6.8$ & $123.4^{\mathrm{b}} \pm 6.3$ & $0.001 *$ \\
\hline Total suspended solids (mg L-1) & $213.91^{\mathrm{e}} \pm 25.1$ & $397.25^{d} \pm 33.0$ & $479.81^{b} \pm 17.0$ & $435.35^{c} \pm 19.4$ & $494.11^{\mathrm{a}} \pm 22$ & $0.001^{*}$ \\
\hline Settleable Solids & $5.6^{\mathrm{a} \pm 1.82}$ & $21.4^{\mathrm{b}} \pm 5.0$ & $21.6^{\mathrm{b}} \pm 4.84$ & $21.8^{\mathrm{b}} \pm 3.45$ & $21.7^{b} \pm 6.54$ & $0.001 *$ \\
\hline
\end{tabular}

*P<0.001; NS, Not significant

Table 3. Growth performance parameters (mean \pm SD) in control and biofloc systems supplemented with different carbon sources. Mean in the same row having different superscript differs significantly at $(P \leq 0.05)$

\begin{tabular}{lccccc}
\hline Parameters & & Treatments & & \\
& Control & BFTf & BFRb & BFWf & BFRf \\
\hline Final body weight & $4.05^{\mathrm{a}} \pm 0.4$ & $4.86^{\mathrm{b}} \pm 0.6$ & $4.48^{\mathrm{ab}} \pm 0.5$ & $5.06^{\mathrm{bc}} \pm 0.3$ & $5.4^{\mathrm{c}} \pm 0.8$ \\
Average daily Growth (g/day) & $0.06^{\mathrm{a}} \pm 0.0$ & $0.07^{\mathrm{b}} \pm 0.0$ & $0.07^{\mathrm{b}} \pm 0.0$ & $0.08^{\mathrm{c}} \pm 0.0$ & $0.08^{\mathrm{c}} \pm 0.0$ \\
Specific growth rate (\%/day) & $6.0^{\mathrm{a}} \pm 0.2$ & $6.3^{\mathrm{b}} \pm 0.2$ & $6.1^{\mathrm{b}} \pm 0.4$ & $6.3^{\mathrm{b}} \pm 0.2$ & $6.4^{\mathrm{b}} \pm 0.1$ \\
Survival \% & $79^{\mathrm{a}} \pm 1.8$ & $84^{\mathrm{b}} \pm 4.2$ & $81^{\mathrm{ab}} \pm 3.9$ & $86^{\mathrm{b}} \pm 2.6$ & $89^{\mathrm{c}} \pm 5.5$ \\
\hline
\end{tabular}


the values were BFTf: $1.9 \times 10^{2}$, BFRf: $1.2 \times 10^{2}$, BFRb: $1.2 \times 10^{2}$, BFWf: $1.0 \times 10^{4}$ and control: $0.8 \times 10^{2}$ respectively. Based on morphological and biochemical characteristics, initially, 55 bacterial isolates were selected from treatments and control. For further identification, 8 isolates, each were chosen from BFTf, $\mathrm{BFRb}$, and BFWf treatments. Ten isolates from BFRf and 5 from control were also chosen.

\section{Sequence Analysis of 16s rRNA Mitochondrial Gene}

Sequence analysis of 16s rRNA revealed the identification of diverse species of bacterial population from each treatment. Strains of Bacillus were observed commonly in treatments and control, whereas strains of Vibrio (V. parahaemolyticus and $V$. alginolyticus) were observed only in control (Figure 6). The BFRf had more diversified Bacillus strains compared to other treatments. Three different photosynthetic bacterial strains belonging to the Rhodobacteraceae (BFT-AP3133) family were only observed in this group (Figure 5.). In BFTf Bacillus strains, Bhargavaea and Photobacterium strains were also observed (Figure 2). In BFRb treatment, bacteria belonging to various genera were observed viz. Bacillus, Pseudoalteromonas (BFT-AP11), Exiguobacterium (BFT-AP11), and Thalassolituus (BFTAP13) compared to other treatments and control (Figure 3). Isolates of the BFWf group belonged to two genera viz. Bacillus and Staphylococcus (Figure 4). All the identified sequences were processed and submitted to GenBank (Accession Number MK966343- MK966378; MK966415- MK966416).

\section{Identification of the Planktonic Composition}

Planktonic composition in the treatments and control was analyzed, revealing significant $(P<0.05)$ differences between treatments and control. (Figure 7). Different groups of planktons viz. Rotifer, copepods, diatoms, cyanobacteria, microalgae, and nematodes were also identified. Overall, from the samples, 38 different species of planktons were identified, including Chlorophyta, Bacteriophyta, Cyanophyta, Ciliophora, Rotifera, and Nematoda. In control, an abundance of filamentous cyanobacteria and nitzschia, sp were observed. Nematodes, along with a considerable amount of cyanobacteria, were commonly found in all treatments and control. (Figure 8)

\section{Expression of Digestive Enzyme and Metabolism- related Genes by Real-time Analysis}

The expression of digestive enzyme-related genes was studied. Trypsin, chymotrypsin, cathepsin L, and cathepsin B genes belong to protein metabolism, while $\alpha$-amylase, pyruvate kinase, triacylglycerol lipase, and fatty acid synthase genes belong to the carbohydrate and fatty acid metabolism. The genes for digestive enzymes were found upregulated in the biofloc treated group compared to the control, the differences being significant. (Figure 9a and9b). Among the treatments, higher fold expression was observed predominantly in BFRf (trypsin: 8.1 fold) (chymotrypsin: 10.2-fold) (cathepsin L: 5.1-fold) (cathepsin B and alpha-amylase: 4.8-fold) and (pyruvate kinase: 7.6-fold) followed by BFRb, BFWf, and BFTf.

\section{Discussion}

In the biofloc system, the carbon source is important to develop and maintain a zero-water exchange system. Though a simple carbon source like molasses effectively immobilizes ammonia, the exploitation of such a source would be high as we rely on a single source. This notion has provoked researchers to explore equally potential, cost-effective, and other locally available carbon sources. It has been revealed that complex carbon sources remove the ammonia slowly compared to simple carbon sources like molasses (Avnimelech, 1999; Ekasari et al., 2014). Many biofloc trials were conducted using simple carbon sources, which are predominantly monosaccharides. However, complex carbon sources such as wheat flour, rice flour, and wheat bran take time for breaking down into simple sugars before utilization. Although they take time, they do stay stable and aid in removing the nitrogen metabolites in the system compared to simple carbohydrates. (Wang et al., 2016; Khanjani et al., 2017). Our study showed significant improvement of water quality parameters in biofloc treatments while using different complex carbon sources. The TAN level reduction was observed in all the treatments compared to the control. The findings of our study are in agreement with those reported by Kuhn et al. (2009). It has been reported that TAN and the carbon sources used in the treatments were utilized by the bacteria to produce microbial floc and new cells. (Avnimelech, 1999). The reduced TAN level aids in promoting a better atmosphere in the culture system. Also, the appropriate level of settleable solids was maintained to retain optimum TSS levels. In our study, an increasing trend was discernible in TSS and settleable solids levels among the treatments. The heterotrophic bacterial populations effectively utilized the supplied complex carbon sources to produce biomass which was reflected in the bacterial count observed in each treatment. Our results corroborate the findings of Rajkumar et al. (2016), who reported similar observations. Abbaszadeh et al. (2019) reported that water quality levels on TAN and TSS were equally maintained in biofloc treatments using the spoilage date palm extract compared to molasses in Penaeus vannamei culture. In our study, complex carbon sources were well utilized for water quality maintenance and for assimilating the nitrogen metabolites. The findings in our study are in accordance with the results reported by Dauda et al. (2017). The authors observed that ammonia reduction and other water quality parameters like TSS were maintained well in rice bran 


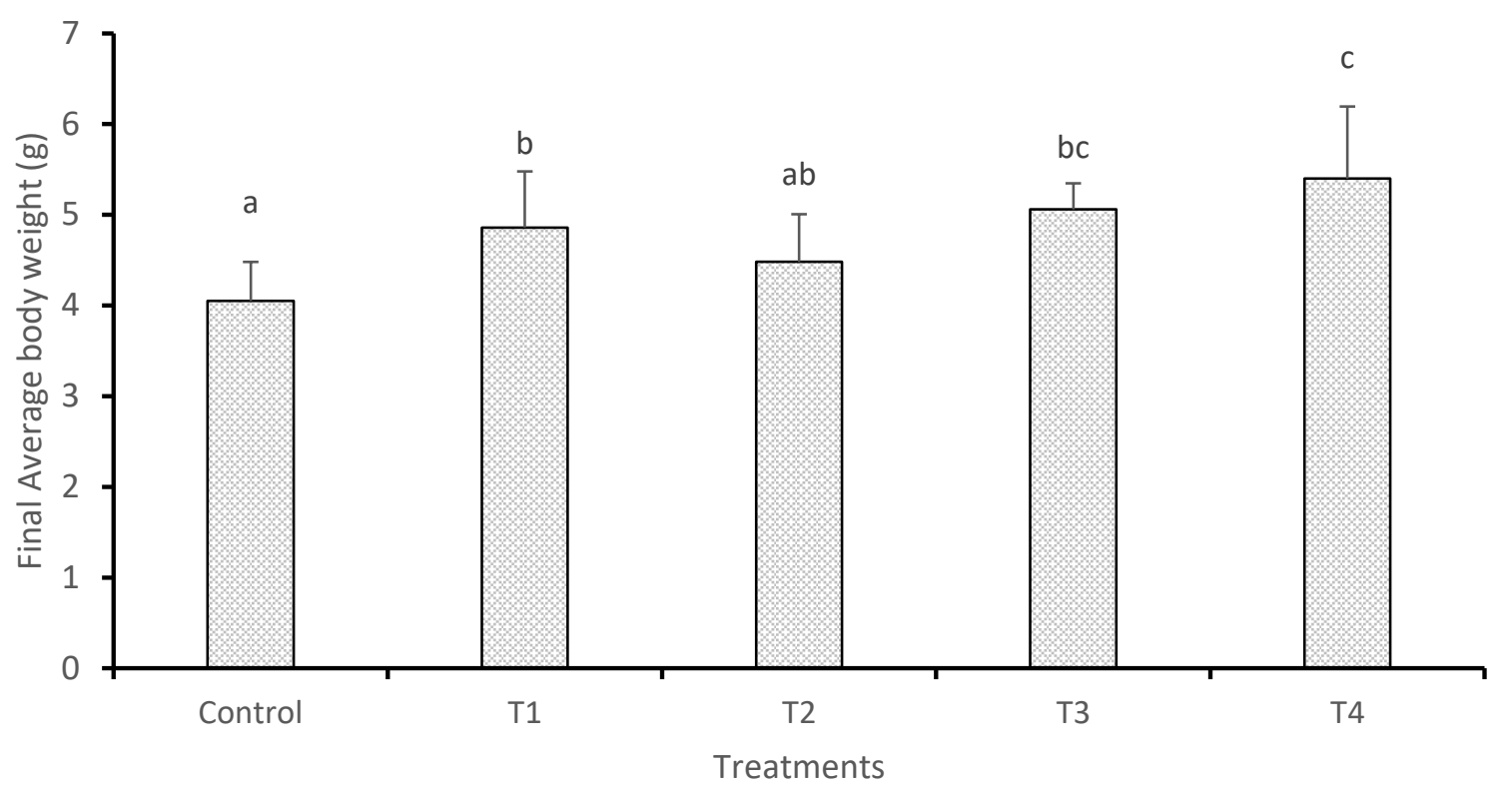

Figure 1. Mean values of body weight of $P$. vannamei in fifteen days interval of four treatments reared in biofloc system supplemented with different carbon source and control. Values are means $( \pm S D)$ of three replicate tanks per sampling time in each group.

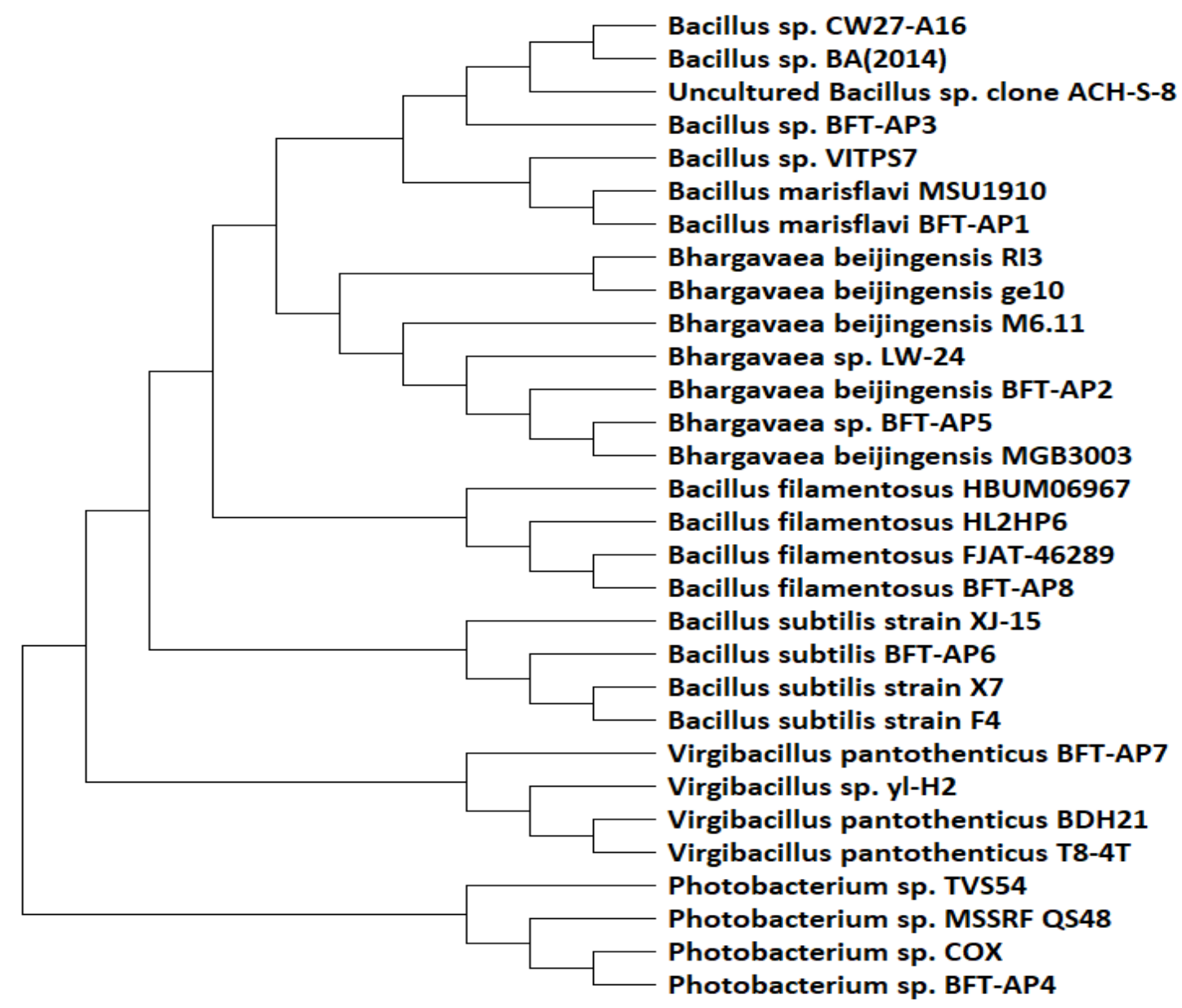

Figure 2. Phylogenetic relationship of identified strains from water samples of BFTf group (Strains names representing BFT-AP are the isolates of this present experiment) 
compared with glycerol and sucrose in African catfish Clarias gariepinus culture under the biofloc system.

Biofloc and carbon sources significantly improved the growth performance of shrimp in all treatments compared to control. Notably, BFRf and BFWf showed improved growth compared to shrimp from other treatments. The addition of carbon sources is advantageous due to their nutritional composition. Panigrahi et al. (2019b) reported the nutritional composition of various carbon sources used in aquaculture. Their inclusion reduces the ammonia level and supports the growth of heterotrophic bacteria. (Panigrahi et al., 2019c). The diverse microbial community observed in each treatment shows that the host animal utilized the carbon source as a supplementary nutritive feed (Deng et al., 2018).
Microbes can use various carbon sources, from simple to complex sugars (Thomsen 2005, Sujeet Kumar et al., 2017). Although rice flour, rice bran (high fiber content), and wheat flour comprise complex sugar with starch and polysaccharides (Zhou et al., 2007), they still render improved water quality, floc development, immunity, and growth. Rice bran is previously reported to give better shrimp yield by enhancing growth and survival and reducing FCR (Vilani et al., 2016). Rajkumar et al. (2016) found that the growth performance of $P$. vannamei was better when complex carbon sources such as wheat flour and tapioca flour were added rather than simple carbon sources such as molasses, a finding similar to what we observed in our study. Zhao et al. (2016) reported that supplying wheat bran (50\%) with molasses $(50 \%)$ for biofloc generation resulted in

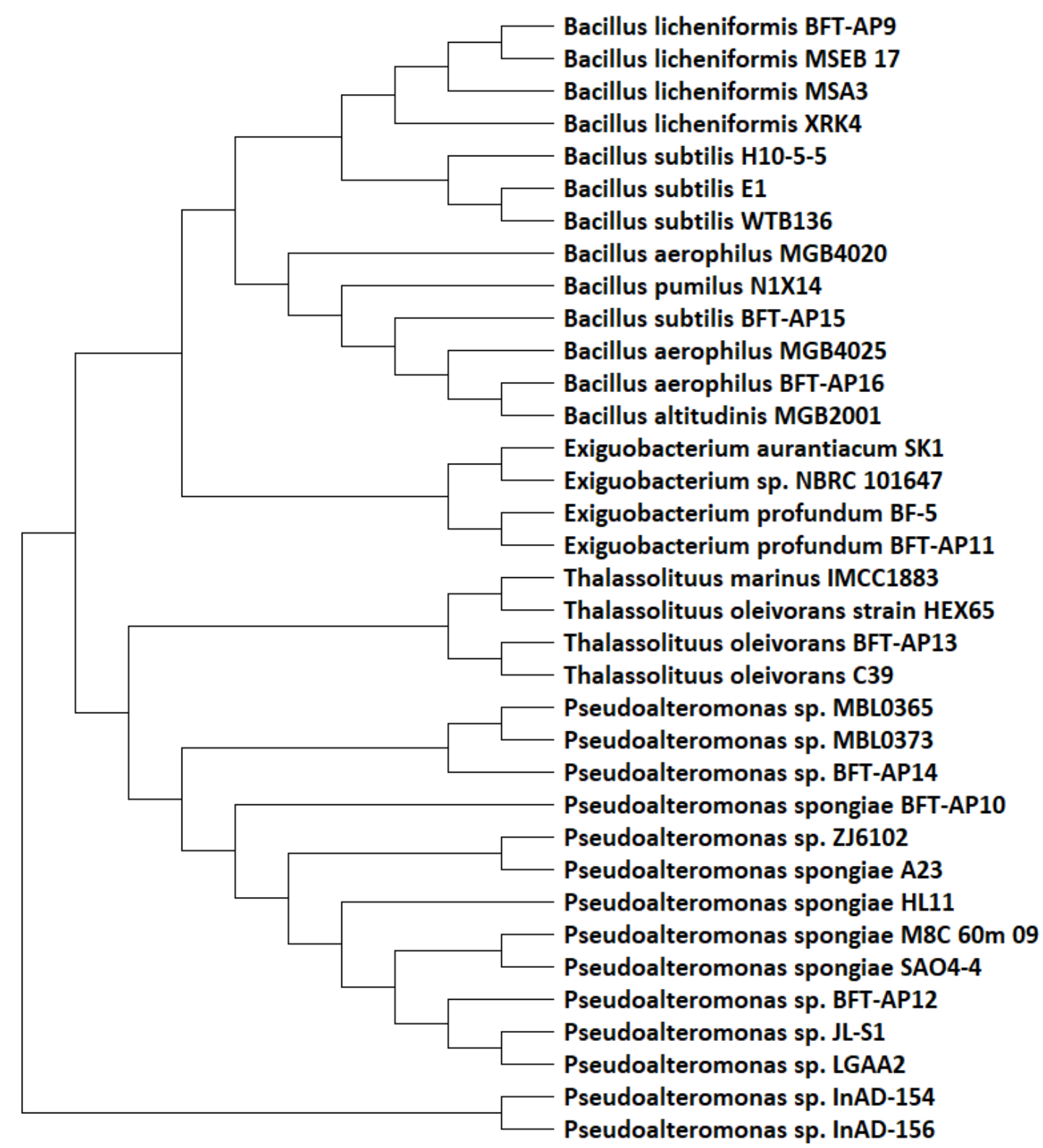

Figure 3. Phylogenetic relationship of identified strains from water samples of BFRb group (Strains names representing BFT-AP are the isolates of this present experiment) 
improved weight gain and SGR in P. vannamei shrimp. Here again, the findings in our study corroborate those of Zhao et al. (2016).

In our study, microbial diversity was observed in response to the addition of complex carbon sources used for biofloc generation. Usually, the type of carbon sources will decide the bacterial abundance in the biofloc system (Deng et., 2018; Wei et al., 2020). Due to the nutritional values of complex carbon sources, the biofloc system harbored a more diversified bacterial abundance. In agreement with this observation, Mabroke et al. (2018) reported that the total bacterial count noticed in control and simple carbon sources is relatively low compared to complex carbon sources like wheat bran. On the contrary, the population of Vibrio in our study substantially reduced in biofloc treatments compared to control. The results align with those we reported in one of our previous studies (Panigrahi et al., 2018), who reported that the increasing C: $N$ ratio in the biofloc system considerably eliminated the Vibrio population. While observing the different strains isolated from other biofloc groups indicated the strains of Bacillus to be common in all the treatments. Bacillus strains are ubiquitous, and many Bacillus strains have been used as probiotics in shrimp culture (Ahmad et al., 2017). The Bacillus genus is mainly observed in biofloc reared animals and the culture environment (Panigrahi et al., 2019c). Zhao et al. (2012) reported that Bacillus strains are observed primarily on biofloc groups, sometimes without the Vibrio group's complete absence. As a natural probiotic, Bacillus is effective against a wide range of pathogenic microbes because of

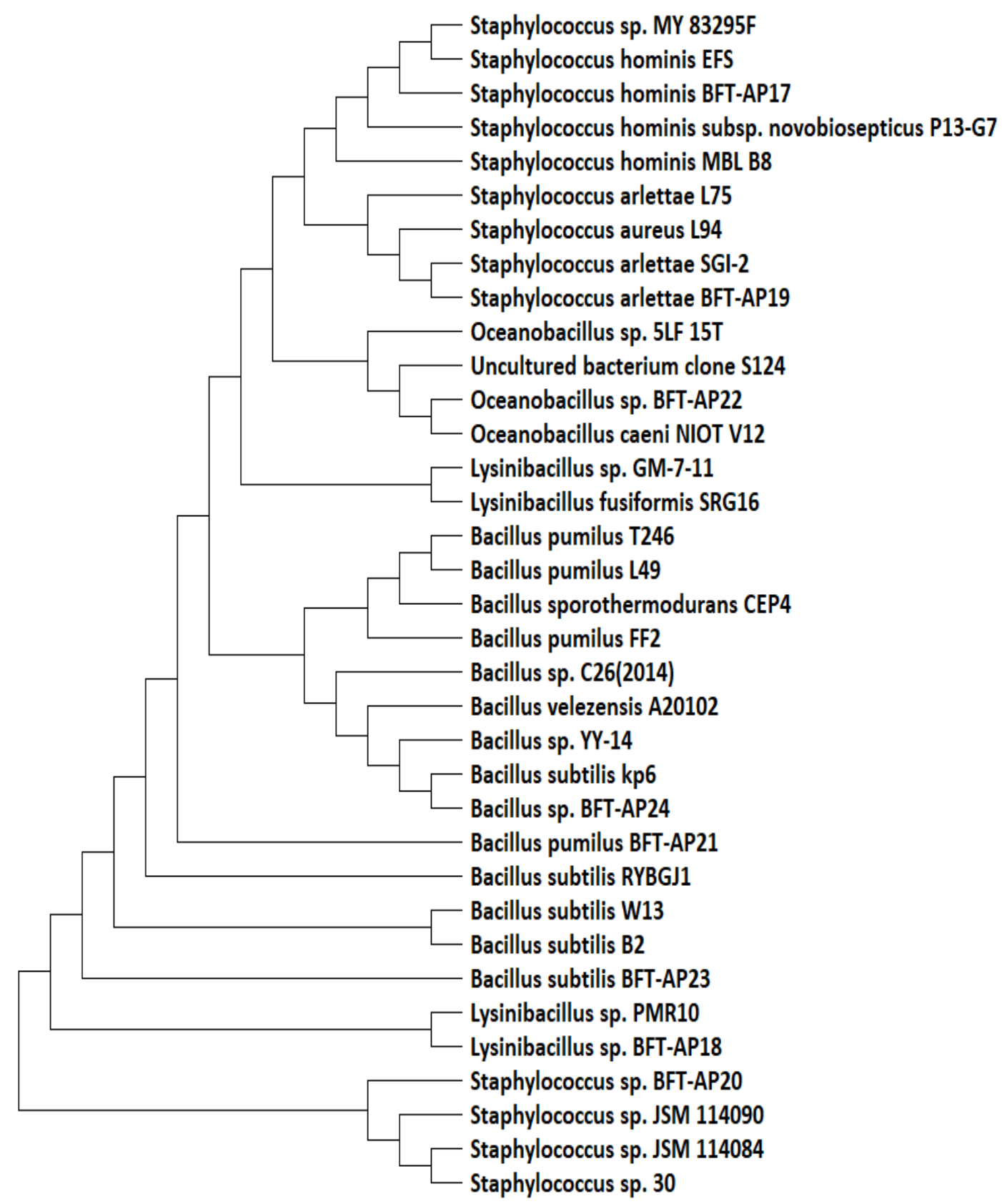

Figure 4. Phylogenetic relationship of identified strains from water samples of BFWf group (Strains names representing BFT-AP are the isolates of this present experiment) 
its ability to produce spores and secondary metabolites (Harun et al., 2017; Bischoff et al.,2019; Soltani et al., 2019).The commonly used bacillus species in aquaculture are Bacillus subtilis (BFT-AP6) (Panigrahi et al., 2020), Bacillus lichiniformis (BFT-AP9) (Elsabagh et al.,2018), Bacillus pumilus (BFT-AP21)(Elsabagh et al., 2018), Bacillus cereus (BFT-AP27)(Reddy et al., 2018), Bacillus megaterium (BFT-AP28)(Hura et al., 2018) and Bacillus amyloliquefaciens (BFT-AP37) (Xie et al., 2013). Bacillus sp improves water quality, improves survival, immunity and enhances shrimp production (Hlordzi et al., 2020).

In contrast, only Vibrio was observed in the control group. The abundance of Bacillus may have a competitive exclusion in inhibiting the growth of Vibrio in treatments. In BFRb, treatment (BFT-AP 10 \&14)
Pseudoalteromonas sp was isolated. They produce extracellular enzymes with anti-bacterial activity (Holmström et al., 1999; Wang et al., 2018). These species were previously reported as a potential promotor of floc formation by aggregating the carbon sources and other organic and inorganic materials in the system (Harun et al., 2018; Hashim et al., 2018). In wheat flour-based treatment (BFT-AP17), Staphylococcus horminis $s p$ was identified, improving immunity and increasing aquaculture production (Rajeswasri et al., 2016). Similarly, In BFRf rice flourbased treatment, mainly Rhodobacteraceae bacterium $s p$ (BFT-AP31) and Roseovarius sp (BFT-AP32) were identified. These bacteria recycle the nutrients by utilizing organic and inorganic compounds, producing secondary metabolites, carbon monoxide oxidation,

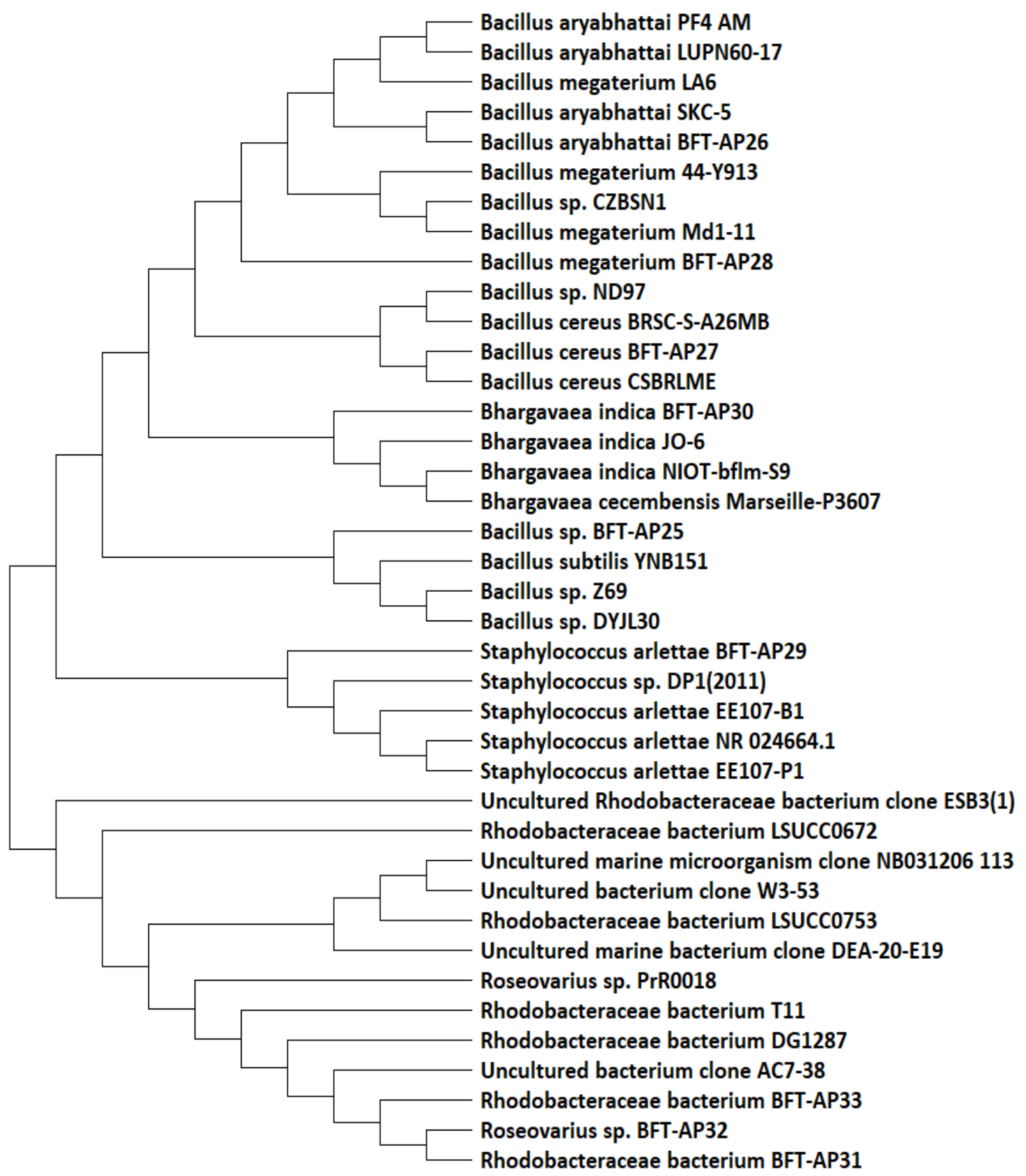

Figure 5. Phylogenetic relationship of identified strains from water samples of BFRf group (Strains names representing BFT-AP are the isolates of this present experiment) 
sulfur oxidation and aerobic activity anoxygenic photosynthesis (Pujalte et al., 2014; Bischoff et al., 2019). They are usually associated with either micro or macroalgae in the high planktonic abundance (Ajani et al., 2018).

Bacteria, fungi, microalgae, protozoans, nematode, rotifer, ciliates, and detritus are the conglomerates in the biofloc system (Emerenciano et al., 2017). They maintain and control water quality, remove toxins, produce microbial biomass, improve the nutritive source and increase the candidate animal's immunity (Kim et al., 2014; Rajkumar et al., 2016; Panigrahi et al., 2018; El-Sayed. 2021). In aquaculture, microalgae are regularly used as feed for shrimps, their nutritional property and active involvement in various nutrient recycling levels are critical (Becerra-Dorame et al., 2011). The microbial population in biofloc treatments is diverse due to the addition of carbon sources (Ju et al., 2009; Panigrahi et al., 2019b; Sundaram et al., 2021). A similar trend was observed in

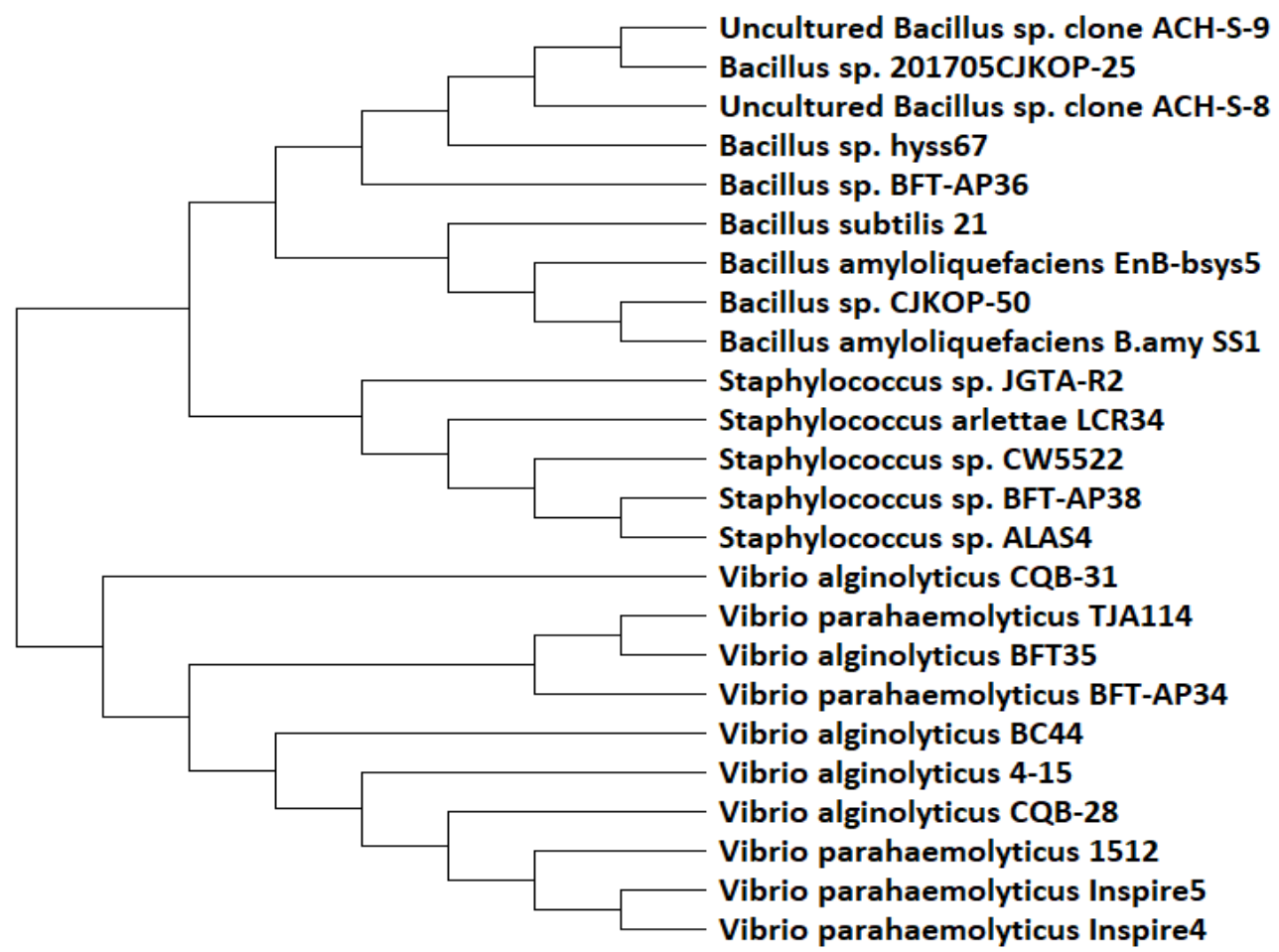

Figure 6. Phylogenetic relationship of identified strains from water samples of control group (Strains names representing BFT-AP are the isolates of this present experiment)

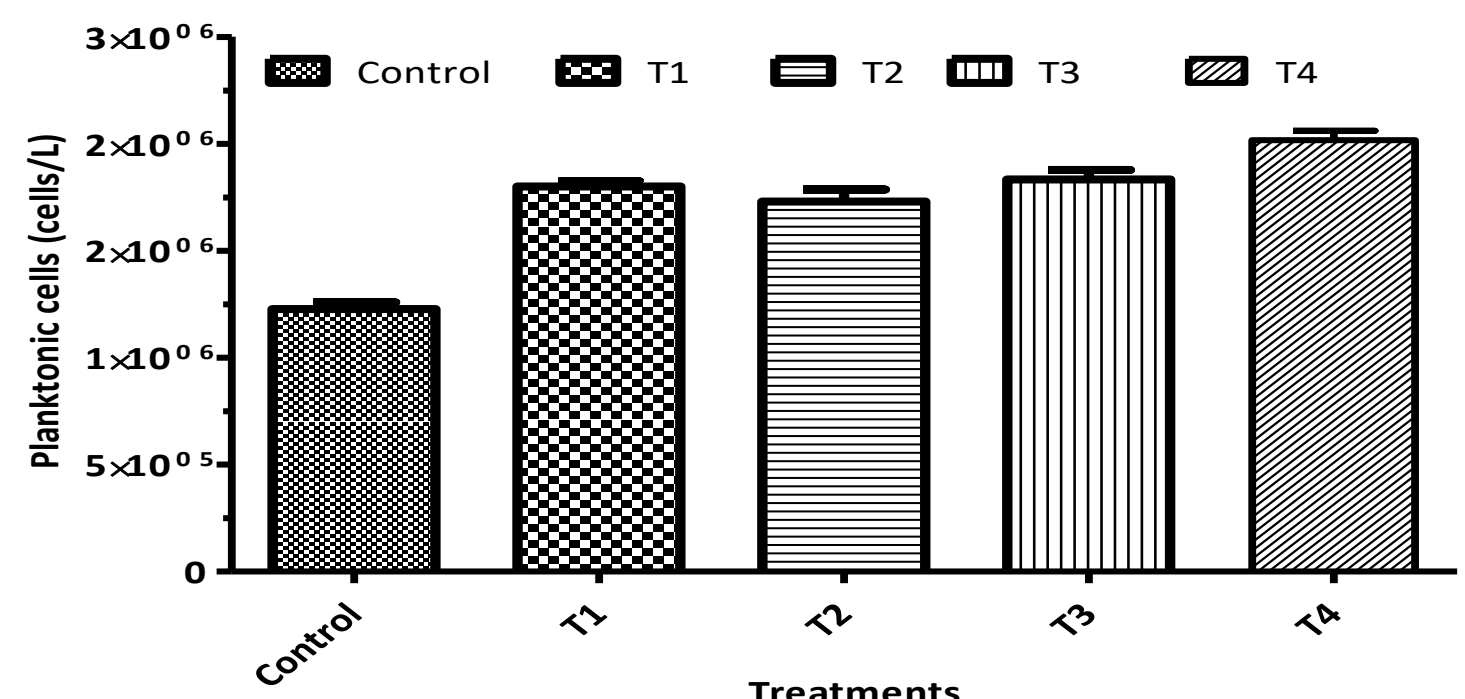

Figure 7. Mean value of planktonic counts present in different treatments (supplemented with different carbon source) and control. Values are means of three replicate tanks per sampling time in each group. 


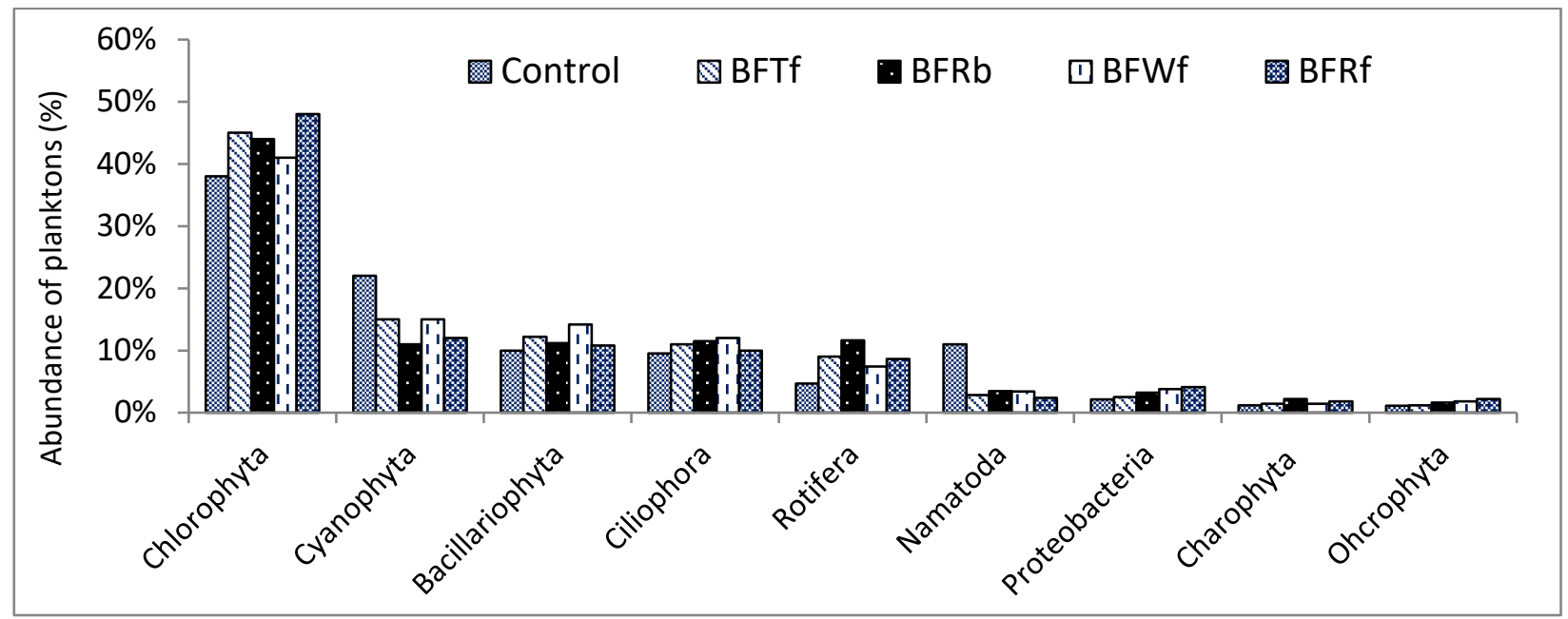

Figure 8. Relative abundance of planktons presents in different carbon source treated biofloc groups and control

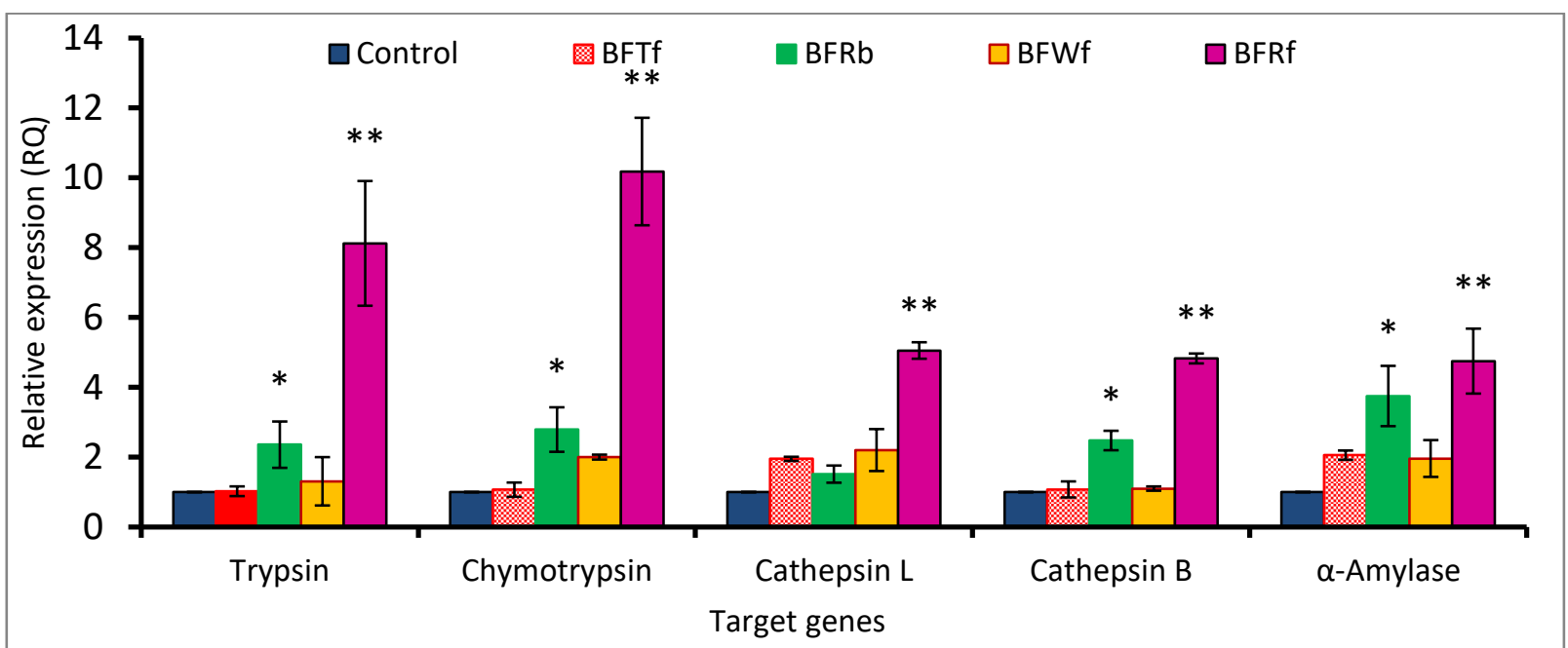

Figure 9a. Relative mRNA expression levels of Trypsin, Chymotrypsin, Cathepsin L, Cathepsin B, and $\alpha$-Amylase gene in P. vannamei reared in biofloc system supplemented with varying complex carbon sources in comparison to that of the control as determined by real-time PCR. Five individual shrimps were analyzed from the control and each of the treatment groups. Data are means \pm SD of gene expression in the different carbon source used treatments. Significant differences between different carbon source added groups are marked with $*, * *(\mathrm{P}<0.05)$.

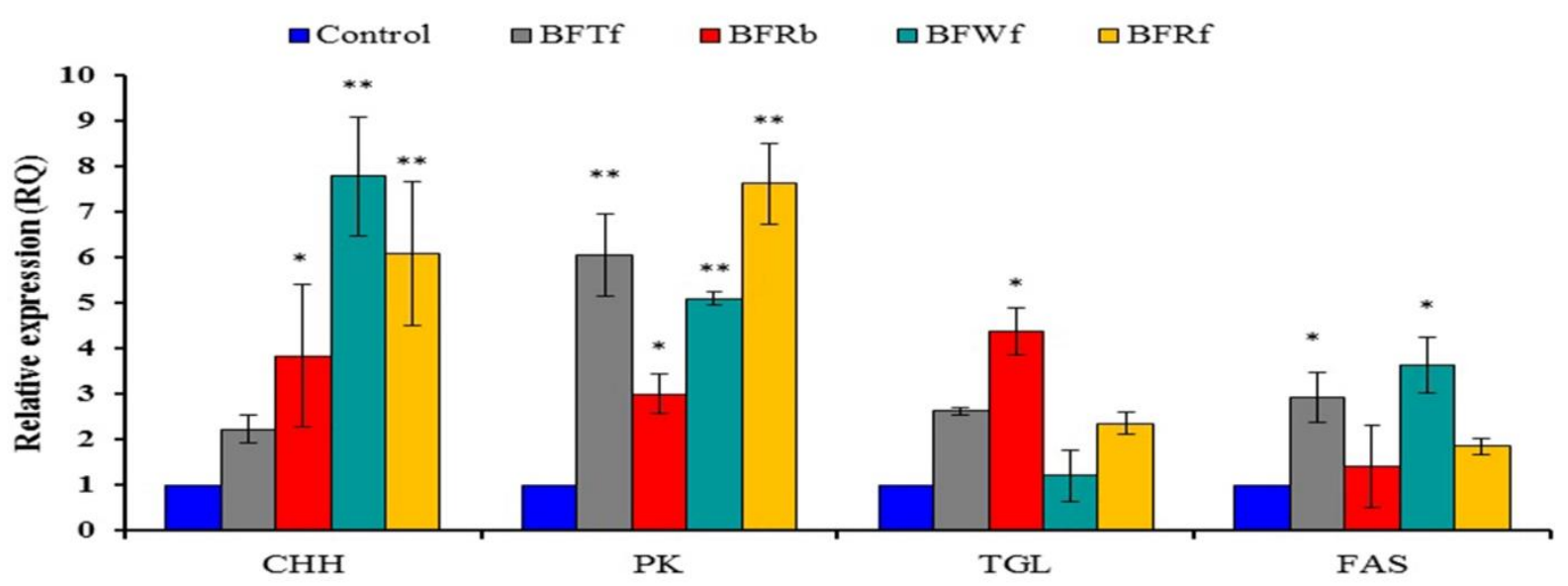

Figure 9b. Relative mRNA expression levels carbohydrate and Fatty Acid metabolism-related genes such as Crustacean Hyperglycemic hormone (CHH), Pyruvate Kinase (PK), Triacylglycerol lipase (TGL), and Fatty acid Synthase (FAS) gene in $P$. vannamei reared in biofloc system supplemented with varying complex carbon sources in comparison to that of the control as determined by real-time PCR. Five individual shrimps were analyzed from the control and each of the treatment groups. Data are means \pm SD of gene expression in the different carbon source used treatments. Significant differences between different carbon source added groups are marked with *, ** $(\mathrm{P}<0.05)$. 
our study. The biofloc treatments generated with different carbon sources were observed to be associated with highly diverse planktonic populations. Planktons serve as a nutritious source for the cultured species (Moss et al., 2001), whereas diatoms and ciliates were observed in low numbers. Rajkumar et al. (2016) and Ray et al. (2010), reported a similar result regarding the plankton community. In general, a higher percentage (41-48\%) of chlorophytes was observed in all the treatments, including the control. Chlorophytes are the dominant microalgae observed in biofloc. Ray et al. (2010) also noticed a similar trend in that chlorophytes were highly propagated microalgae in $P$. vannamei culture. Likewise, Maicá et al. (2012) noted an abundance of chlorophytes and diatoms in $P$. vannamei biofloc culture. Lezama-Cervantes et al., (2010) observed that shrimp graze different species of cyanobacteria. Cyanophyta also plays a vital role in nutrient recycling, but many researchers have explained that higher profusion cyanobacteria could be toxic (Beccera-dorome et al., 2011). Simultaneously, Cyanophyta is a primary producer or decomposer in the food chain by incorporating nitrogen (Manan et al., 2016). In our study, the abundance of Cyanophyta and bacillariophyta are nearly similar, followed by a profusion of Rotifera and Ciliophora. Other essential species in biofloc are the Ciliates and Nematodes. Ray et al. (2010) reported that the presence of nematodes and ciliates is correlated. Nematodes and ciliates serve as rich live feed for the animals reared (Jiménez-Ordaz et al., 2021 Silva et al.,2021). Other zooplanktons such as Rotifera and Copepods are rich in nutrients that serve as a live feed in the biofloc system and play a vital role in the food chain in the aquatic system (Ballester et al., 2010; Asaduzzaman et al. 2010). Many bacterial species from proteobacteria were isolated in our study.

The effect of biofloc generated with complex carbon sources on the expression of genes related to digestive enzyme activity was studied. It was observed that shrimp cultured in biofloc exhibited upregulation of digestive enzyme-associated genes, the expression being exceptionally high in BFRf. Five genes viz. trypsin, chymotrypsin, cathepsin L, cathepsin B, Alpha-amylase were taken up for the study relating to the digestive enzymes. Among the five genes, trypsin and chymotrypsin are the mainly proteolytic enzymes present in the decapods, responsible for protein digestion (Muhlia-Almazan et al., 2003; Panigrahi et al., 2019a). Proteolytic enzymes can be significantly affected when there is low food availability or in the presence of non-nutritive food. Biofloc system ensures the continuous availability of food to host animals. Different beneficial bacteria utilize the availability of a higher ratio of carbon source, and the secondary metabolites produced by the bacteria stimulate the digestive enzyme activity of shrimps. Earlier, it was observed that the increasing $\mathrm{C}$ : $\mathrm{N}$ ratio might stimulate proteolytic and amylolytic activity in the digestive gland and stomach (Xu and Pan, 2012; Xu et al., 2013).
Penaeus vannamei grown on mixed carbon sources of molasses, cornflour, and wheat bran increased protease, lipase, and amylase activity (Wang et al., 2016). Likewise, Becerra-Dorame et al. (2012) reported that Penaeus vannamei possess relatively high protease and amylase enzyme activity when reared in heterotrophic systems than in the autotrophic system. Hence, the availability of high carbon sources and C: $\mathrm{N}$ ratio provide a better environment and ensures the continuous possibility of food for the host species (Panigrahi et al., 2021). Accordingly, the digestive enzyme activity was found to be better in biofloc reared shrimp.

Simultaneously, the Crustacean Hyperglycemic Hormone $(\mathrm{CHH})$ was found to be upregulated in biofloc treatments. The $\mathrm{CHH}$ functions as a regulator of glucose level in shrimp and participates in the metabolism of carbohydrates and fatty acids. It has an additional role in reproduction, osmoregulation, and ecdysis (Wanlem et al., 2011). Chung et al. (2010) reported that when crustaceans require extra energy, they switch to glycolysis, an anaerobic energy pathway modulated by $\mathrm{CHH}$ mainly during stress or when they tend to have low hemolymph glucose. The upregulated expression of $\mathrm{CHH}$ correlated with glucose is directly proportional to the digestion of carbon sources by the digestive enzymes (Chakrapani et al., 2021). In addition, pyruvate kinase is also upregulated in biofloc reared animals and acts as a key regulatory enzyme in glycolysis-mediated energy transformation. They catalyze the irreversible transphosphorylation of phosphoenolpyruvate to pyruvate and ATP (Valentini et al., 2002; Sánchez-Paz et al., 2008).

Lipid metabolism is an essential source of energy reserve, used when there is food scarcity for homeostasis and when animals encounter highly fluctuating environments. Lipid utilization varies depending on the changes in seasons (Martínez-Alarcón et al., 2020) and when the animals fight for survival in extreme conditions. Fatty acid synthase (FAS) and triacylglycerol lipase (TGL) are enzymes involved in lipid metabolism. The FAS is a multifunctional enzyme that catalyzes the synthesis of fatty acids (Chakrapani et al., 2021). Yang et al. (2011) reported that FAS counteracts against pathogenic white spot syndrome virus (WSSV) and $V$. parahemolyticus bacterial infection (Zuo et al., 2016). During homeostasis conditions, FAS maintains vitality. The upregulation of FAS and TGL indicates that it influences shrimp immunity and the utilization of lipids in the system (Chen et al., 2015), respectively. Subsequently, the enhanced digestive enzyme activity in the metabolism of carbohydrates, proteins, and lipids gives better performance. Complex carbon sources effectively affect ammonia assimilation and improve digestive enzyme activity by stimulating bio-active compounds in the biofloc system. Therefore, complex carbon sources are equally capable like any other simple carbon source. 


\section{Conclusion}

Of late, biofloc technology is being developed as a sustainable culture practice in aquaculture. The supplementation of locally available carbon sources and their suitability to the biofloc system is an essential strategy for the success of this technology. The complex carbon sources were tested as substitutes for molasses. Results revealed the improved performance of shrimp in BFRf (rice flour) and BFWf (Wheat flour) complex carbon sources compared to control. Therefore, it could be concluded that the complex carbon sources such as rice flour and wheat flour are equally efficient in assimilating nitrogen metabolites, developing diverse microbial populations, providing better digestibility, enhancing growth, and increasing production in the biofloc system.

\section{Ethical Statement}

Ethics approval: The research undertaken complies with the current animal welfare laws in India. The study was undertaken with the approval of the statutory authorities of the Central Institute of Brackishwater Aquaculture, Chennai, India. The experimental animal Penaeus vannamei is not an endangered shrimp; the provisions of the Govt. of India's Wildlife Protection Act of 1972 are not applicable for experiments on this shrimp.

\section{Funding Information}

The work was financially support provided by the Department of Biotechnology (DBT), India, and the National Fisheries Development Board (NFDB).

\section{Author Contribution}

CS- drafting the manuscript, conducted experiment, performed sampling and analyzing the samples and data interpretation, AP- planning of the study, critical evaluation, data interpretation and fund mobility, SJ-Conducted Experiment, MS- Conducted experiment and provided valuable suggestions to the manuscript, PE- reviewed and provided valuable suggestions to the manuscript, SRV-analyzed the samples, AK-Sampling and data collection

\section{Conflict of Interest}

The author(s) declare that they have no known competing financial or non-financial, professional, or personal conflicts that could have appeared to influence the work reported in this paper.

\section{Acknowledgements}

The authors are grateful for the financial support provided by the Department of Biotechnology (DBT), India, and the National Fisheries Development Board
(NFDB). Special thanks are due to the Director, ICARCentral Institute of Brackishwater Aquaculture, for providing the necessary facilities and Dr. G. Gopikrishna, Ex-HoD, Head of NGDB division (NGBD) for his suggestions. We are grateful to all the reviewers for improving this manuscript.

\section{References}

Abbaszadeh, A., Yavari, V., Hoseini, S.J., Nafisi, M., \&TorfiMozanzadeh, M. (2019). Effects of different carbon sources and dietary protein levels in a biofloc system on growth performance, immune response against white spot syndrome virus infection and cathepsin L gene expression of $P$. vannamei. Aquaculture Research, 50(4),11621176. https://doi.org/10.1111/are. 13991

Ahmad, I., Rani, A.B., Verma, A.K., \&Maqsood, M. (2017). Biofloc technology: an emerging avenue in aquatic animal healthcare and nutrition. Aquaculture International, 25(3), 1215-1226. https://doi.org/10.1007/s10499-016-0108-8

Ajani, P.A., Kahlke, T., Siboni, N., Carney, R., Murray, S.A., \& Seymour, J.R. (2018). The microbiome of the cosmopolitan diatom Leptocylindrus reveals significant spatial and temporal variability. Frontiers in microbiology, 9, 2758.

https://doi.org/10.3389/fmicb.2018.02758

APHA (American Public Health Association), American Water Works Association, Water Environment Federation. (1998). Standard Methods for the Examination of Water and Wastewater, 20th ed. APHA, Washington, DC. http: [//hdl.handle.net/1969.3/24401.

Asaduzzaman, M., Rahman, M.M., Azim, M.E., Islam, M.A., Wahab, M.A., Verdegem, M.C.J., \&Verreth, J.A.J. (2010). Effects of $\mathrm{C} / \mathrm{N}$ ratio and substrate addition on natural food communities in freshwater prawn monoculture ponds. Aquaculture, 306(1-4), 127-136. https://doi.org/10.1016/j.aquaculture.2010.05.035

Avnimelech, Y. (1999). Carbon/nitrogen ratio as a control element in aquaculture systems. Aquaculture, 176(3-4), 227-235.

https://doi.org/10.1016/S0044-8486(99)00085-X

Avnimelech, Y. (2009). Biofloc technology: a practical guide book. World Aquaculture Society. ISBN: 9781888807165

Bakhshi, F., Najdegerami, E.H., Manaffar, R., Tukmechi, A., \& Farah, K.R. (2018). Use of different carbon sources for the biofloc system during the grow-out culture of common carp (Cyprinus carpio L.) fingerlings. Aquaculture, 484, 259-267. https://doi.org/10.1016/j.aquaculture.2017.11.036

Becerra-Dorame, M.J., Martínez-Porchas, M., MartínezCórdova, L.R., Rivas-Vega, M.E., Lopez-Elias, J.A., \& Porchas-Cornejo, M.A. (2012). Production response and digestive enzymatic activity of the Pacific white shrimp Litopenaeus vannamei (Boone, 1931) intensively pregrown in microbial heterotrophic and autotrophicbased systems. The Scientific World Journal, 2012. https://doi.org/10.1100/2012/723654

Becerra-Dorame, M.J., Martínez-Córdova, L.R., MartínezPorchas, M., \& Lopez-Elías, J.A. (2011). Evaluation of autotrophic and heterotrophic microcosm-based systems on the production response of Litopenaeus vannamei intensively nursed without Artemia and with zero water exchange. 
http://hdl.handle.net/10524/36290

Bischoff, V., Zucker, F., and Moraru, C. (2019) Marine Bacteriophages. In Reference Module in Life Sciences pp $1-20$

Bossier, P., \& Ekasari, J. (2017). Biofloc technology application in aquaculture to support sustainable development goals. Microbial biotechnology, 10(5), 1012-1016. https://doi.org/10.1111/1751-7915.12836

Cai, J., Zhou, X., Yan, X., Lucente, D., \&Lagana, C. (2019). Top 10 species groups in global aquaculture 2017. FAO, Rome, Italy, 12.

Crab, R., Defoirdt, T., Bossier, P., \&Verstraete, W. (2012). Biofloc technology in aquaculture: Beneficial effects and future challenges. Aquaculture. https://doi.org/10.1016/j.aquaculture.2012.04.046

Chakrapani, S., Panigrahi, A., Sundaresan, J., Sivakumar, M.R. Palanisamy, R., \& Kumar, V. (2021). Three different C: N ratios for Pacific white shrimp, Penaeus vannamei under practical conditions: Evaluation of growth performance, immune and metabolic pathways. Aquaculture Research, 52(3), 1255-1266.

https://doi.org/10.1111/are.14984

Chen, K., Li, E., Xu, Z., Li, T., Xu, C., Qin, J.G., \& Chen, L. (2015). Comparative transcriptome analysis in the hepatopancreas tissue of pacific white shrimp Litopenaeus vannamei fed different lipid sources at low salinity. PLoS One, 10(12), e0144889. https://doi.org/10.1371/journal.pone.0144889

Chung, J.S., Zmora, N., Katayama, H., \& Tsutsui, N. (2010). Crustacean hyperglycemic hormone (CHH) neuropeptides family: functions, titer, and binding to target tissues. General and comparative endocrinology, 166(3), 447-454. https://doi.org/10.1016/j.ygcen.2009.12.011

Dauda, A.B., Romano, N., Ebrahimi, M., Karim, M., Natrah, I., Kamarudin, M.S., \&Ekasari, J. (2017). Different carbon sources affects biofloc volume, water quality and the survival and physiology of African catfish Clariasgariepinus fingerlings reared in an intensive biofloc technology system. Fisheries science, 83(6), 1037-1048.https://doi.org/10.1007/s12562-017-1144-7

Deng, M., Chen, J., Gou, J., Hou, J., Li, D., \& He, X. (2018). The effect of different carbon sources on water quality, microbial community and structure of biofloc systems. Aquaculture, 482, 103-110. https://doi.org/10.1016/j.aquaculture.2017.09.030

Ekasari, J., Azhar, M.H., Surawidjaja, E.H., Nuryati, S., De Schryver, P., \& Bossier, P. (2014). Immune response and disease resistance of shrimp fed biofloc grown on different carbon sources. Fish \& shellfish immunology, 41(2), 332-339.

https://doi.org/10.1016/j.fsi.2014.09.004

Elsabagh, M., Mohamed, R., Moustafa, E.M., Hamza, A., Farrag, F., Decamp, O., ... \& Eltholth, M. (2018). Assessing the impact of Bacillus strains mixture probiotic on water quality, growth performance, blood profile and intestinal morphology of Nile tilapia, Oreochromis niloticus. Aquaculture nutrition, 24(6), 1613-1622. https://doi.org/10.1111/anu.12797

El-Sayed, A.F.M. (2021). Use of biofloc technology in shrimp aquaculture: a comprehensive review, with emphasis on the last decade. Reviews in Aquaculture, 13(1), 676-705. https://doi.org/10.1111/raq.12494s

Emerenciano, M., Gaxiola, G., \&Cuzon, G. (2013). Biofloc technology (BFT): a review for aquaculture application and animal food industry. Biomass now-cultivation and utilization, 301-328. http://doi.org/10.5772/53902

Emerenciano, M.G.C., Martínez-Córdova, L.R., MartínezPorchas, M., \& Miranda-Baeza, A. (2017). Biofloc technology (BFT): a tool for water quality management in aquaculture. Water quality, 5, 92-109. https://www.intechopen.com/chapters/53211

Gálvez, A.O. (2015). Plankton communities in shrimp monoculture, integrated biofloc system. CEP, 52171, 900.

Hargreaves, J.A. (2006). Photosynthetic suspended-growth systems in aquaculture. Aquacultural Engineering, 34(3), 344-363. https://doi.org/10.1016/j.aquaeng.2005.08.009

Harun, A.A.C., Ghazali, N. A., Hashim, N.F.C., Mohammad, N.A.H., Ikhwanuddin, M., Ismail, N., ... \&Kasan, N.A. (2018). The potential of bioflocculant producing bacteria as inoculum for biofloc based systems. Journal of Environmental Biology, 39(5), 917-922. http://doi.org/10.22438/jeb/39/5(SI)/9

Hashim, N.F.C., Ghazali, N.A., Amin, N.M., Ismail, N., \&Kasan, N.A. (2018). Description of novel marine bioflocculantproducing bacteria isolated from biofloc of Pacific whiteleg shrimp, Litopenaeusvannamei culture ponds. BioRxiv, 402065.https://doi.org/10.1101/402065

Hlordzi, V., Kuebutornye, F.K., Afriyie, G., Abarike, E.D., Lu, Y., Chi, S., \& Anokyewaa, M.A. (2020). The use of Bacillus species in maintenance of water quality in aquaculture: A review. Aquaculture Reports, 18, 100503. https://doi.org/10.1016/j.aqrep.2020.100503

Hollender, J., van der Krol, D., Kornberger, L., Gierden, E., \&Dott, W. (2002). Effect of different carbon sources on the enhanced biological phosphorus removal in a sequencing batch reactor. World Journal of Microbiology and Biotechnology, 18(4), 359-364.

https://doi.org/10.1023/A:1015258308460

Holmström, C., \& Kjelleberg, S. (1999). Marine Pseudoalteromonas species are associated with higher organisms and produce biologically active extracellular agents. FEMS microbiology ecology, 30(4), 285-293. https://scielo.conicyt.cl/pdf/lajar/v49n1/0718-560Xlajar-49-01-0155.pdf

Hura, M.U.D., Zafar, T., Borana, K., Prasad, J.R., \& Iqbal, J. (2018). Effect of commercial probiotic Bacillus megaterium on water quality in composite culture of major carps. International Journal of Current Agricultural Sciences, 8(1), 268-273.

Jamal, M.T., Broom, M., Al-Mur, B.A., Al Harbi, M., Ghandourah, M., Al Otaibi, A., \& Haque, M.F. (2020). Biofloc Technology: Emerging Microbial Biotechnology for the Improvement of Aquaculture Productivity. Polish Journal of Microbiology, 69(4), 401. https://doi.org/10.33073/pjm-2020-049

Jiménez-Ordaz, F.J., Cadena-Roa, M.A., Pacheco-Vega, J.M., Rojas-Contreras, M., Tovar-Ramírez, D., \& ArceAmezquita, P.M. (2021). Microalgae and probiotic bacteria as biofloc inducers in a hyper-intensive Pacific white shrimp (Penaeus vannamei) culture. Latin american journal of aquatic research, 49(1), 155-168. http://dx.doi.org/10.3856/vol49-issue1-fulltext-2442.

Ju, Z.Y., Forster, I.P., \&Dominy, W.G. (2009). Effects of supplementing two species of marine algae or their fractions to a formulated diet on growth, survival and composition of shrimp (Litopenaeus vannamei). Aquaculture, 292(3-4), 237-243. 
https://doi.org/10.1016/j.aquaculture.2009.04.040

Khanjani, M.H., Sajjadi, M.M., Alizadeh, M., \&Sourinejad, I. (2017). Nursery performance of Pacific white shrimp (Litopenaeus vannamei Boone, 1931) cultivated in a biofloc system: the effect of adding different carbon sources. Aquaculture Research, 48(4), 1491-1501. https://doi.org/10.1111/are.12985

Kuhn, D.D., Boardman, G.D., Lawrence, A.L., Marsh, L., Flick, G.J., (2009). Microbial floc meals as a replacement ingredient for fish meal and soybean protein in shrimp feed. Aquaculture, 296, 51-57.

https://doi.org/10.1016/j.aquaculture.2009.07.025

Lezama-Cervantes, C., \& Paniagua-Michel, J. (2010). Effects of constructed microbial mats on water quality and performance of Litopenaeus vannamei post-larvae. Aquacultural Engineering, 42(2), 75-81. https://doi.org/10.1016/j.aquaeng.2009.12.002

Mabroke, R.S., Ashraf, M.A.S. Goda., Rania, S. Mabroke., Mohamed, Soaudy. (2018). Complexity of carbon sources and the impact on biofloc integrity and quality in tilapia (Oreochromis niloticus) tanks. AACL Bioflux, 11(3). https://www.bioflux.com.ro/docs/2018.846-855.pdf

Maicá, P.F., de Borba, M.R., \& Wasielesky Jr, W. (2012). Effect of low salinity on microbial floc composition and performance of Litopenaeus vannamei (Boone) juveniles reared in a zero-water-exchange super-intensive system. Aquaculture Research, 43(3), 361-370. https://doi.org/10.1111/j.1365-2109.2011.02838.x

Manan, H., Moh, J.H.Z., Kasan, N.A., Suratman, S., \& Ikhwanuddin, M. (2017). Identification of biofloc microscopic composition as the natural bioremediation in zero water exchange of Pacific white shrimp, Penaeus vannamei, culture in closed hatchery system. Applied Water Science, 7(5), 2437-2446. https://doi.org/10.1007/s13201-016-0421-4

Mani, S., Ramasamy, S.M., Chakrapani, S., Krishna, A., PS, S.A., Lalramchhani, C., ... \& Panigrahi, A. (2021). The effect of natural and artificial periphytic substrates with biofloc system on shrimp Penaeus vannamei (Boone 1931) culture: growth and immune response. Aquaculture International, 29(2), 651-668. https://doi.org/10.1007/s10499-021-00646-0

Martínez-Alarcón, D., Hagen, W., Held, C., \& Saborowski, R. (2020). Molecular aspects of lipid metabolism in the midgut gland of the brown shrimp Crangon crangon. Comparative Biochemistry and Physiology Part B: Biochemistry and Molecular Biology, 248, 110465. https://doi.org/10.1016/j.cbpb.2020.110465

Mugwanya, M., Dawood, M.A., Kimera, F., \& Sewilam, H. (2021). Biofloc systems for sustainable production of economically important aquatic species: A review. Sustainability, 13(13), 7255.

https://doi.org/10.3390/su13137255

Muhlia-Almazán, A., Garcia-Carreño, F.L., Sánchez-Paz, J.A., Yepiz-Plascencia, G., \&Peregrino-Uriarte, A.B. (2003). Effects of dietary protein on the activity and mRNA level of trypsin in the midgut gland of the white shrimp Penaeus vannamei. Comparative Biochemistry and Physiology Part B: Biochemistry and Molecular Biology, 135(2), 373-383. https://doi.org/10.1016/S10964959(03)00091-5

Pfaffl, M.W. (2001). A new mathematical model for relative quantification in real-time RT-PCR. Nucleic acids research, 29(9), e45-e45.

https://doi.org/10.1093/nar/29.9.e45
Panigrahi, A., Esakkiraj, P., Das, R.R., Saranya, C., Vinay, T.N., Otta, S.K., \& Shekhar, M.S. (2021). Bioaugmentation of biofloc system with enzymatic bacterial strains for high health and production performance of Penaeus indicus. Scientific reports, 11(1), 1-13.

https://doi.org/10.1038/s41598-021-93065-3

Panigrahi, A., Esakkiraj, P., Jayashree, S., Saranya, C., Das, R.R., \&Sundaram, M. (2019c). Colonization of enzymatic bacterial flora in biofloc grown shrimp Penaeus vannamei and evaluation of their beneficial effect. Aquaculture International, 27(6), 1835-1846. https://doi.org/10.1007/s10499-019-00434-x

Panigrahi, A., Saranya, C., Sundaram, M., Vinoth Kannan, S.R., Das, R.R., Satish Kumar, R., Rajesh, P., \&Otta, S.K. (2018). Carbon: Nitrogen $(C: N)$ ratio level variation influences microbial community of the system and growth as well as immunity of shrimp (Litopenaeus vannamei) in biofloc based culture system. Fish and Shellfish Immunology. https://doi.org/10.1016/j.fsi.2018.07.035

Panigrahi, A., Sundaram, M., Jebha, J., Syamadayal, J., Otta, S.K., Bhuvaneswari, T., Saraswathy, R., ShyneAnand, P.S., Rajababu, D., Saranya, C., Gopal, C., \&Ravichandran, P. (2017). Biofloc based nutrient dense culture system for nursery and grow-out farming of pacific white shrimp Penaeusvannameiboone, 1931. Indian Journal of Fisheries. https://doi.org/10.21077/ijf.2017.64.specialissue.76189-04

Panigrahi, A., Das, R.R., Sivakumar, M.R., Saravanan, A., Saranya, C., Sudheer, N.S., ... \& Gopikrishna, G. (2020). Bio-augmentation of heterotrophic bacteria in biofloc system improves growth, survival, and immunity of Indian white shrimp Penaeus indicus. Fish \& shellfish immunology, 98, 477-487. https://doi.org/10.1016/j.fsi.2020.01.021

Panigrahi, A., Sundaram, M., Saranya, C., Kumar, R.S., Dayal, J.S., Saraswathy, R., ... \& Gopal, C. (2019a). Influence of differential protein levels of feed on production performance and immune response of pacific white leg shrimp in a biofloc-based system. Aquaculture, 503, 118-127. https://doi.org/10.1016/j.aquaculture.2018.12.036

Panigrahi, A., Sundaram, M., Saranya, C., Swain, S., Dash, R.R., \& Dayal, J.S. (2019b). Carbohydrate sources deferentially influence growth performances, microbial dynamics and immunomodulation in Pacific white shrimp (Litopenaeus vannamei) under biofloc system. Fish \& shellfish immunology, 86, 1207-1216.

https://doi.org/10.1016/j.fsi.2018.12.040

Pennak, R.W. (1989). Fresh-water invertebrates of the United States. Protozoa to mollusca. (ed. 2): 1-769. (John Wiley and Sons, Inc., New York).

Pohlner, M., Dlugosch, L., Wemheuer, B., Mills, H., Engelen, B., \& Reese, B.K. (2019). The majority of active Rhodobacteraceae in marine sediments belong to uncultured genera: A molecular approach to link their distribution to environmental conditions. Frontiers in microbiology, 10, 659. https://doi.org/10.3389/fmicb.2019.00659

Pujalte, M.J., Lucena, T., Ruvira, M.A., Arahal, D.R., \& Macián, M.C. (2014). The Family Rhodobacteraceae. The Prokaryotes: Alphaproteobacteria and Betaproteobacteria. Rosenberg E, Delong EF, Lory S, Stackebrandt E, and Thompson F.(eds.), 439-512.

Rajkumar, M., Pandey, P.K., Aravind, R., Vennila, A., Bharti, V., \&Purushothaman, C.S. (2016). Effect of different biofloc 
system on water quality, biofloc composition and growth performance in Litopenaeus vannamei (Boone, 1931). Aquaculture Research, 47(11), 3432-3444. https://doi.org/10.1111/are.12792

Rajeswari, V., Priyadarshini, S.K., Saranya, V., Suguna, P., \& Shenbagarathai, R. (2016). Immunostimulation by phospholipopeptide biosurfactant from Staphylococcus hominis in Oreochromis mossambicus. Fish \& shellfish immunology, 48, 244-253. https://doi.org/10.1016/j.fsi.2015.11.006

Ray, A.J., Seaborn, G., Leffler, J.W., Wilde, S.B., Lawson, A., \&Browdy, C.L. (2010). Characterization of microbial communities in minimal-exchange, intensive aquaculture systems and the effects of suspended solids management. Aquaculture, 310(1-2), 130-138. https://doi.org/10.1016/j.aquaculture.2010.10.019

Reddy, K.V., Reddy, A.V.K., Babu, B.S., \& Lakshmi, T.V. (2018). Applications of Bacillus $s p$ in aquaculture waste water treatment. Int JS Res Sci. Tech, 4, 1806-1812.

Romano, N., Dauda, A.B., Ikhsan, N., Karim, M., \& Kamarudin, M.S. (2018). Fermenting rice bran as a carbon source for biofloc technology improved the water quality, growth, feeding efficiencies, and biochemical composition of African catfish Clarias gariepinus juveniles. Aquaculture research, 49(12), 3691-3701. https://doi.org/10.1111/are.13837

Sánchez-Paz, A., Soñanez-Organis, J.G., Peregrino-Uriarte, A.B., Muhlia-Almazán, A., \&Yepiz-Plascencia, G. (2008). Response of the phosphofructokinase and pyruvate kinase genes expressed in the midgut gland of the Pacific white shrimp Litopenaeus vannamei during short-term starvation. Journal of experimental marine biology and ecology, 362(2), 79-89. https://doi.org/10.1016/j.jembe.2008.06.002

Shaun M. Moss, Steve M. Arce, Brad J. Argue, CleteA.Otoshi, Fernanda R.O. Calderon, and A.G.J.T. (2001). Greening of the blue revolution: Efforts toward environmentally responsible shrimp culture. New Wave Proceedings of the Special Session on Sustainable Shrimp Farming, September 2015, 1-19.

Silva, D.A., de Lima, P.C.M., da Silva, A.E.M., de Oliveira Filho, P.R.C., da Silva, S.M.B.C., Olivera Gálvez, A., \& Brito, L.O. (2021). Effects of adding rotifers on the water quality, plankton composition and growth of Pacific white shrimp, Litopenaeus vannamei juvenile, when cultured with biofloc technology. Aquaculture Research. https://doi.org/10.1111/are.15276

Soltani, M., Ghosh, K., Hoseinifar, S.H., Kumar, V., Lymbery, A.J., Roy, S., \& Ring ø, E. (2019). Genus Bacillus, promising probiotics in aquaculture: aquatic animal origin, bioactive components, bioremediation and efficacy in fish and shellfish. Reviews in Fisheries Science \& Aquaculture, 27(3), 331-379. https://doi.org/10.1080/23308249.2019.1597010

Mani, S., Ramasamy, S.M., Chakrapani, S., Krishna, A., PS, S.A., Lalramchhani, C., ... \& Panigrahi, A. (2021). The effect of natural and artificial periphytic substrates with biofloc system on shrimp Penaeus vannamei (Boone 1931) culture: growth and immune response. Aquaculture International, 29(2), 651-668.

https://doi.org/10.1007/s10499-021-00646-0

Thomsen, M.H. (2005). Complex media from processing of agricultural crops for microbial fermentation. Applied Microbiology and Biotechnology, 68(5), 598-606. https://doi.org/10.1007/s00253-005-0056-0
Valentini, G., Chiarelli, L.R., Fortin, R., Dolzan, M., Galizzi, A., Abraham, D.J. \& Mattevi, A. (2002). Structure and function of human erythrocyte pyruvate kinase Molecular basis of nonspherocytichemolyticanemia. Journal of Biological Chemistry, 277(26), 23807-23814. https://doi.org/10.1074/jbc.M202107200

Verma, A.K., Rani, A.B., Rathore, G., Saharan, N., \& Gora, A.H. (2016). Growth, non-specific immunity and disease resistance of LabeorohitaagainstAeromonashydrophila in biofloc systems using different carbon sources. Aquaculture, 457, 61-67. https://doi.org/10.1016/j.aquaculture.2016.02.011

Vilani, F.G., Schveitzer, R., da Fonseca Arantes, R., do Nascimento Vieira, F., do Espírito Santo, C.M., \&Seiffert, W.Q. (2016). Strategies for water preparation in a biofloc system: Effects of carbon source and fertilization dose on water quality and shrimp performance. Aquacultural Engineering, 74, 70-75. https://doi.org/10.1016/j.aquaeng.2016.06.002

Wang, C., Pan, L., Zhang, K., Xu, W., Zhao, D., \& Mei, L. (2016). Effects of different carbon sources addition on nutrition composition and extracellular enzymes activity of bioflocs, and digestive enzymes activity and growth performance of Litopenaeus vannamei in zero-exchange culture tanks. Aquaculture research, 47(10), 3307-3318. https://doi.org/10.1111/are.12784

Wang, X., Li, E., \& Chen, L. (2016). A review of carbohydrate nutrition and metabolism in crustaceans. North American Journal of Aquaculture, 78(2), 178-187. https://doi.org/10.1080/15222055.2016.1141129

Wang, H., Wang, C., Tang, Y., Sun, B., Huang, J., \& Song, X. (2018). Pseudoalteromonas probiotics as potential biocontrol agents improve the survival of Penaeus vannamei challenged with acute hepatopancreatic necrosis disease (AHPND)-causing Vibrio parahaemolyticus. Aquaculture, 494, 30-36. https://doi.org/10.1016/j.aquaculture.2018.05.020

Wanlem, S., Supamattaya, K., Tantikitti, C., Prasertsan, P., \&Graidist, P. (2011). Expression and applications of recombinant crustacean hyperglycemic hormone from eyestalks of white shrimp (Litopenaeus vannamei) against bacterial infection. Fish \& shellfish immunology, 30(3), 877-885. https://doi.org/10.1016/j.fsi.2011.01.014

Wei, Y., Liao, S.A., \& Wang, A.L. (2016). The effect of different carbon sources on the nutritional composition, microbial community and structure of bioflocs. Aquaculture, 465, 88-93. https://doi.org/10.1016/j.aquaculture.2016.08.040

Wei, Y., Wang, A., \& Liao, S. (2020). Effect of different carbon sources on microbial community structure and composition of ex-situ biofloc formation. Aquaculture, 515. https://doi.org/10.1016/j.aquaculture.2019.734492

Xie, F., Zhu, T., Zhang, F., Zhou, K., Zhao, Y., \& Li, Z. (2013). Using Bacillus amyloliquefaciens for remediation of aquaculture water. SpringerPlus, 2(1), 1-5. https://doi.org/10.1186/2193-1801-2-119

Xu, W.J., \& Pan, L.Q. (2012). Effects of bioflocs on growth performance, digestive enzyme activity and body composition of juvenile Litopenaeus vannamei in zerowater exchange tanks manipulating $\mathrm{C} / \mathrm{N}$ ratio in feed. Aquaculture, 356-357, 147-152. https://doi.org/10.1016/j.aquaculture.2012.05.022 
Xu, W.J., Pan, L.Q., Sun, X.H., \& Huang, J. (2013). Effects of bioflocs on water quality, and survival, growth and digestive enzyme activities of Litopenaeus vannamei (Boone) in zero-water exchange culture tanks. Aquaculture Research, 44(7), 1093-1102. https://doi.org/10.1111/j.1365-2109.2012.03115.x

Yang, L., Liu, J., Liu, M., Qian, M., Zhang, M., \& Hu, H. (2011). Identification of fatty acid synthase from the Pacific white shrimp, Litopenaeus vannamei and its specific expression profiles during white spot syndrome virus infection. Fish \& shellfish immunology, 30(2), 744-749. https://doi.org/10.1016/j.fsi.2010.12.026

Zhao, D., Pan, L., Huang, F., Wang, C., \& Xu, W. (2016). Effects of different carbon sources on bioactive compound production of biofloc, immune response, antioxidant level, and growth performance of Litopenaeus vannamei in zero-water exchange culture tanks. Journal of the World Aquaculture Society, 47(4), 566-576. https://onlinelibrary.wiley.com/doi/epdf/10.1111/jwas. 12292
Zhao, P., Huang, J., Wang, X.H., Song, X.L., Yang, C.H., Zhang, X.G., \& Wang, G.C. (2012). The application of bioflocs technology in high-intensive, zero exchange farming systems of Marsupenaeusjaponicus. Aquaculture, 354, 97-106.

https://doi.org/10.1016/j.aquaculture.2012.03.034

Zhou, Z., Ding, Z., \& Huiyuan, L.V. (2007). Effects of dietary short-chain fructooligosaccharides on intestinal microflora, survival, and growth performance of juvenile white shrimp, Litopenaeus vannamei. Journal of the World Aquaculture Society, 38(2), 296-301. https://doi.org/10.1111/j.1749-7345.2007.00099.x

Zuo, H., Gao, J., Yuan, J., Deng, H., Yang, L., Weng, S., ... \& Xu, X. (2017). Fatty acid synthase plays a positive role in shrimp immune responses against Vibrio parahaemolyticus infection. Fish \& shellfish immunology, 60, 282-288. https://doi.org/10.1016/j.fsi.2016.11.054 